REVISTA DE DERECHO UNED, núm. 4, 2009

\title{
CONSIDERACIONES EN TORNO A LA DIFAMACIÓN ESCRITA EN DERECHO ROMANO*
}

\author{
(NOTES ABOUT WRITTEN DEFAMATION \\ IN ROMAN LAW)
}

\begin{abstract}
RAQuel Escutia Romero
Profesora de Derecho Romano de la Universidad Autónoma de Madrid. Doctora en Derecho
\end{abstract}

Resumen: El presente artículo versa sobre el origen de la represión de la difamación escrita en Derecho romano. Partiendo de un breve esbozo sobre la regulación en la Ley de las XII Tablas del malum carmen y de la iniuria y su posterior desarrollo a través de los edictos especiales emanados por el pretor, las reflexiones se centran en el surgimiento, difusión y represión de la escritura difamatoria, carmen aut libelli famosi, en la época de la República tardía.

Palabras clave: carmen famosum, iniuria, edictum ne quid infamandi causa fiat, libelli famosi

Abstract: The following article deals with the repression of written defamation in Roman law. Starting from a thumbnail sketch of the regulation in the XII Tables law, as regards of malum carmen, iniuria and it subsequent development by the praetor through the emanation of special edicts, reflections will be focus on the emergence, dissemi-

* El presente artículo se enmarca en el Proyecto de Investigación concedido por el Ministerio de Ciencia e Innovación titulado «La Jurisdiccion Voluntaria: un mandato legislativo pendiente de cumplimiento. cuestiones generales», bajo la dirección del investigador principal, el Profesor A. Fernández de Buján, con la referencia DER200806460-C02-01/JURI. 
nation and repression of the defamatory writing — carmen aut libelli famosi- in the late Roman Republic times.

Key words: carmen famosum, iniuria, edictum ne quid infamandi causa fiat, libelli famosi

Sumario: I. Introducción.-II. Aspectos generales de la intervención pretoria en la actio iniuriarum.-III. Intervención pretoria en la difamación escrita. carmen condere- ne quid infamandi causa fiat.

\section{INTRODUCCIÓN}

Durante los años 451-450 a.C se fecha la publicación de la Ley de las XII Tablas que constituye un hito en la historia del Derecho Romano ${ }^{1}$, tanto por la superación de las insuficiencias del ordenamiento jurídico, como por su contribución definitiva al edificio de la constitución ciudadana consistente en haber dotado de certeza a las normas jurídicas que regulaban la vida ciudadana. Las XII Tablas ${ }^{2}$ representan una legislación primitiva no completa ${ }^{3}$ que, sin embargo, revela claramente hasta qué punto el sentido de igualdad social, la protección de la libertad y el respeto a la autonomía individual eran ya aspectos fundamentales de la convivencia romana; convivencia y autonomía individual que podían verse afectadas por aquellas palabras injuriosas, tanto orales como escritas, que lesionaban la dignidad de la persona, entre ellas los denominados escritos difamatorios.

${ }^{1}$ FERNÁNDEZ DE BUJÁN, A., Derecho Público Romano. Recepción, Jurisdicción y Arbitraje, 11. ${ }^{\mathrm{a}}$ ed. Madrid 2008 pp. 91 ss.

${ }^{2}$ Sobre la Ley de las XII Tablas VOIGT. M, Die XII Tafeln Geschichte und System des Civil-und Criminal-Rechtes, wie Processes der XII Tafeln nebst deren Fragmenten. Zweiter Band: Das Civil-und Criminalrecht der XII Tafeln, Leipzig 1883. RICCOBONO, La lex XII Tabularium, Rivista di legislazione comparata, vol. I, 1904, pp. 5 ss. RAGUSA, Le XII Tavole, Atenaeum, Roma 1925, pp. 63 ss. (referencia a la tabla 8). APPLETON, Notre enseignement du droit romain ses ennemis et ses défauts, Mélanges de Droit Romain dédiés a Georges Cornil. Tomo I, Paris 1926, pp. 44 ss. CORNIL, Ancien Droit Romain. Le problèmedes origines, Paris 1930 pp. 78 ss.

${ }^{3}$ A pesar de la apreciación de Livio $(3,34,6)$ «fons omnis publici privatique iuris» en palabras del Prof. Fernández de Buján A. «no abarca en su totalidad el derecho vigente, pero sí su mayor parte, en especial las normas que regulan las relaciones entre los ciudadanos, lo que supone certeza, objetividad y seguridad jurídica... constituyen asimismo un intento de sistematización y orden expositivo del derecho que servirá de base al edicto del pretor y a las posteriores obras del derecho civil. Supone asimismo un primer intento de separación entre el ius, derecho laico, secularizado y el fas, imperativos religiosos y morales». 
La represión de la escritura difamatoria durante este periodo ha sido estudiada e interpretada de muy diversas maneras, tanto por estudiosos romanistas y filólogos como por historiadores del derecho, cuyas aportaciones básicamente pueden agruparse en las siguientes interpretaciones:

- En primer lugar, la difamación escrita estaría incluida en la norma que prohíbe los encantamientos mágicos Tab 8.1 a), es decir, los denominados mali carmina, en una segunda parte Tab.8.1 b) dedicada a los carmina famosi y, por tanto, las XII Tablas reprimirían con pena capital, además de las palabras mágicas o encantadoras, también las difamatorias, o como comúnmente se dice, además del carmen malum también el carmen famosum ${ }^{4}$.

- En segundo lugar se encuentran los autores que sostienen todo lo contrario, que las XII Tablas no se han ocupado, en modo alguno, de la difamación verbal sino que únicamente recogen las fórmulas de encantamiento, de manera que en época decemviral sólo se habrían reprimido los mali carmina.

- En tercer lugar podría hablarse de una teoría intermedia que postula que, aunque las XII Tablas sólo contemplan los mali carmina como fórmulas mágicas, éstas también podrían difamar a aquellos frente a quienes se dirigían.

- Finalmente, en cuarto lugar se ha planteado la posibilidad de que la escritura difamatoria pudiera constituir parte del delito de iniuria en los términos establecidos en este momento: bien siendo el carmen famosum uno de los supuestos especiales de iniuriae o quizá, más bien, entrando en la noción genérica de iniuria como acto non iure ${ }^{5}$.

Todas estas tendencias desarrolladas a lo largo del siglo pasado, principalmente en la primera mitad del mismo $^{6}$, han constituido una

\footnotetext{
${ }^{4}$ MANFREDINI, La Diffamazione verbale nel dirirtto romano, I, Età Repubblicana, Milán, 1979, pp. 1 ss.

${ }^{5}$ D. 47, 10,1 pr. Iniuria ex eo dicta est, quod non iure fiat.

${ }^{6}$ Respecto a la doctrina de principios de siglo XX.- HUVELIN, Les tablettes magiques et le droit romain, Études d'Historie du Droit Commercial Romain. Paris 1929. BECKMANN, Zauberei und Recht in Roms Frühzeit, Münster, 1923. FRAENKEL, Franz, Beckmann, Zauberei und Recht in Roms Frühzeit, Münster, 1923, Gnomon 1, 1925, pp. 185 ss. SMITH, The Law of libel at Rome, CQ.XLV, 1951 pp. 169 ss. LINDSAY, Defamation and the Law unter Sulla, CPh. XLIV 1949, pp. 240 ss. HENDRICKSON, Verbal injury, magic, or erotic cosmus? CPh. XX, 1925 pp. 289 ss. DESPORT, Proyect d'une étude sur la notion de Carmenet son expression dans la literature latine,
} 
larga y fructífera doctrina que sigue manteniendo el interés de los estudiosos actuales ${ }^{7}$. La disparidad de opiniones y la falta de unidad en el tema son fruto de la escasez de fuentes, tanto jurídicas como literarias, y de la posible corrupción en la interpretación de las mismas, debido a que las referencias histórico-jurídicas de la época decemviral nos son dadas por autores que escriben con dos o más siglos de distancia entre los acontecimientos que narran y el momento en el que los narran.

Por ello, es propia de la época tratada esa falta de unidad en la doctrina de todo cuanto atañe al estudio del carmen famosum, malum carmen y la iniuria decemviral; una falta de unidad que resulta imposible de solventar cuando hemos de remontarnos a época tan primitiva $^{8}$ y a la vez «oscura». Quizá lo único que admita la doctrina pacíficamente es la existencia en la tabla 8.1. a) y b), de los términos malum carmen y occentare sive carmen condere, así como la presencia en la tabla 8.2 del término iniuria. Pero el contenido específico de dichos términos dado por el legislador decemviral es totalmente controvertido.

Sentemos pues como punto de partida si las XII Tablas reprimían con pena capital además de las palabras mágicas o encantadoras, también las difamatorias, o como tradicionalmente se considera, si además del carmen malum también el carmen famosum.

REL.20, 1942 pp. 40 ss. HENDRICKSON, Occentare Ostium bei Plautus, Hermes 61, 1926 pp. 78 ss. FRANK, Naevius and free spreech, AJPh. XLVIII 2 pp. 105 ss. RADIN, Freedom of Spreech in Ancient Athenes, AJPh. XLVIII 1, pp. 215 ss. RONCONI, «Malum carmen» e «malus poeta», Synteleia Arangio-Ruiz 2, Nápoles 1964, pp. 958971.

${ }^{7}$ Vid al respecto la doctrina más actual: CASTILLO, M.S, Estudio sobre la casuística de las lesiones en la jurisprudencia romana, Madrid 1994, RodRíguez DíAz, E, A propósito de la actio iniuriarum, III Congreso Iberoamericano de Derecho Romano, León 6, 7 y 8 de febrero 1997, pp. 349 ss. HAGEMANN, M., Iniuria, Von den XII- Tafeln bis zur Justinianischen Kodifakation, Köln, Weimar, Wien, 1998. DE LAPUERTA MONTOYA, Estudio sobre el «edictum de ademptata pudicitia», Valencia 1999. FERNÁNDEZ PRIETO, La difamación en el Derecho romano, Valencia 2002. GUERRERO LEBRÓN, M., La protección jurídica del honor postmortem en Derecho Romano y en Derecho Civil, Granada 2002. GUERRERO LEBRÓN, M., La injuria indirecta en Derecho Romano, Colección Monografías de Derecho Romano Dirigidas por Pr. Dr. D. Antonio Fernández de Buján, Dykinson, Madrid 2005. BRAVO BOSCH, M. ${ }^{a}$ J., La injuria verbal colectiva, Colección Monografías de Derecho Romano Dirigidas por Pr. Dr. D. Antonio Fernández de Buján, Dykinson, Madrid, 2007. MOLLÁ, S., «Relación entre iniuria e iniuria iudicis», en Liber amicorum Juan Miquel estudios romanísticos con motivo de su emeritazgo, Barcelona, 2006.

${ }^{8}$ FERNANDEZ PRIETO, La Difamación en el derecho romano, cit. p. 21. 
El mencionado debate, que fue objeto de profundos análisis sólo a partir de los inicios del siglo $\mathrm{XX}^{9}$, ha constituido desde entonces objeto de permanente estudio por parte de filólogos, historiadores y romanistas (no sin polémica de forma especial entre los filólogos e historiadores $)^{10}$ de finales del siglo $\mathrm{XX}^{11}$. Cabe asimismo destacar el interés demostrado sobre esta temática por los estudiosos de comienzos de este siglo, en especial, en el marco de la doctrina romanista española ${ }^{12}$. Representa, en consecuencia, el tema objeto de nuestro estudio, al decir de MANFREDINI, uno de los así llamados «temas eternos» sobre el que no se terminará nunca de escribir ${ }^{13}$.

Las líneas interpretativas fundamentales, tal y como hemos expresado, son dos: la primera, denominada difamatoria, que postula que las XII Tablas habrían considerado junto a las fórmulas de en-

${ }^{9}$ Se puede sin duda afirmar que el tema ha sido objeto de profundo análisis exegético e histórico a partir del notable trabajo de USENER, Italische Volksjustiz, en Rheim Museum 56, 1900. También en Kleine Schriften, IV, Leipzig, Berlin, 1903; en éste el autor avala la tesis de que las XII Tablas reprimían en la occentatio un caso de difamación verbal, pero al mismo tiempo inicia la obra de desmontaje crítico de la tradición tardorepublicana y clásica relativa a tal ilícito en las XII Tablas, planteando la hipótesis, como se verá a continuación, de la presencia de una glosa en la formulación del precepto traído por Agustín civ. 2,9 que cita literalmente a Cicerón, y da una explicación histórica plausible del hecho descrito por los decenviros con el término occentare; con ésto se salía de la vaga y estereotipada noción del carmen famosum hasta ese momento dominant. Casi contemporáneamente, el tema era retomado por aquellos autores que han originado las bases para la tendencia o interpretación mágica: HUVELIN, Les Tablettes magiques et le droit romain, cit., pp. 219 ss. (ya con anterioridad en Ann. Int. d'hist. Congr. Paris 2, 1902); La notion de l'iniuria dans le très ancien droit romain, Lyon 1903, pp. 18 ss. MASCHKE, Die Persönlichkeitsrechte des römischen Injuriensystem, Breslau, 1903, pp. 11 ss.

${ }^{10}$ Véanse las fuertes fricciones de FRAENKEL, rec a BECKMANN, Zauberei und Rech in Roms Frühzeit, Osnabrück 1923, en Gnomon 1, 1925, pp. 189 ss., contra el jurista que «deviato dalla caccia delle interpolazioni nel digesto vede una glossa in Cic, rep. 4,12»

${ }^{11}$ MANFREDINI, Contributo allo studio dell'iniuria in etá repubblicana, Milano 1977; MANFREDINI, La Diffamazione verbale nel dirirtto romano, I, Età Repubblicana, cit., passim; MANFREDINI, L'iniuria nelle XII tavole. Intestabilis ex lege (Cornelia de iniuriis). Derecho romano de Obligaciones. Homenaje al Profesor José Luis Gener. Madrid 1994, p799-809. MANFREDINI, Quod edictum autem praetorum de aestimandis iniuriis, en Illicito e pena privata in etá repubblicana (Atti convegno Copanello 1990), Napoli 1992. BALZARINI, "De iniuria extra ordinem statui» Contributi allo studio del diritto penale romano dell'età classica, Padua, 1983.

${ }^{12}$ FERNÁNDEZ PRIETO, La difamación en el Derecho romano, cit., passim. GUERRERO LEBRÓN, M., La protección jurídica del honor postmortem en Derecho Romano y en Derecho Civil, cit., passim. GUERRERO LEBRÓN, M., La injuria indirecta

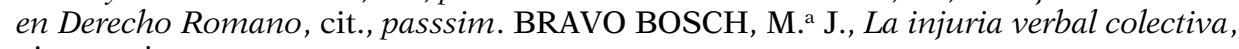
cit., passim.

${ }^{13}$ MANFREDINI, La Diffamazione..., cit., p. 1. 
cantamiento (mala carmina) aquellas dirigidas a lesionar la fama (carmina famosa); y la segunda que definiremos como mágica, que sostiene por el contrario que las XII Tablas no se han ocupado, en absoluto, de la difamación verbal sino única y exclusivamente de las fórmulas de encantamiento. Sin ahondar en profundidad en el desarrollo de todos los argumentos que la sustentan nos adherimos a la interpretación mágica considerando que la difamación escrita no fue recogida en ninguna de las normas decemvirales ${ }^{14}$, no fue castigada como malum carmen (tab.8.1a), puesto que esta norma sólo se refería a fórmulas mágicas ${ }^{15}$; no fue tampoco integrada en la tabla 8.1 b) donde tradicionalmente se recoge la locución referida por S. Agustín como propia de Cicerón occentare sive carmen condere quod infamiam faceret flagitiumve alteri ${ }^{16}$; ni tampoco puede considerarse incluida dentro de la noción decenviral de iniuria (tab.8.4), puesto que

${ }^{14}$ FERnÁNDEZ DE BUJÁN, A., Derecho Público Romano. Recepción, Jurisdicción y arbitraje, 11. ${ }^{\mathrm{a}}$ ed. Madrid 2008, pp. 91 ss.

${ }^{15}$ El estado de las fuentes, tanto jurídicas como literarias, nos permite afirmar que la legislación decemviral no contempló en ninguno de sus preceptos, ni la represión de los insultos u ofensas verbales, ni la de los escritos infamantes. La reconstrucción que de la tab. 8.1 a) a través del texto de Plinio Nat, 28, 17 debe considerarse originaria del precepto que castigaba los mala carmina, correcta desde un punto de vista estilístico y lexical, además de plenamente atendible desde el punto de vista sustancial. Estos carmina eran las fórmulas mágicas de encantamiento pronunciadas con la finalidad de dañar.

El malum carmen era, por tanto, el encantamiento que turbaba la armonía preestablecida y que en una sociedad latina arcaica, todavía ligada a una concepción del mundo religiosa, era digno de la más severa represión. En este contexto, no es raro que la fórmula de encantamiento dirigida a turbar el equilibrio entre los signos positivos y negativos (ley de la Némesis), pueda ser entendida como un gravísimo ilícito susceptible de la pena de muerte.

${ }^{16}$ Los textos de San Agustín Civ. 2, 9, que recoge las palabras de Cicerón «si quis occentavisset sive carmen condidisset quod infamiam faceret flagitiumve alteri", y de Horacio epist. 2, 1, 152-155 ... lex/ poenaque lata, malo quae nollet carmine quequam/ describi: vertere modum formidine fustis/ ad bene dicendum delectandumque redacti, por los que se ha interpretado que se remonta a las XII Tablas la represión de los escritos difamatorios entendiendo que los términos occentare sive carmen condere designan el hecho de recitar y escribir carmina famosa no pueden considerarse como una fuente creíble. La locución «occentare sive carmen condere» no parece pues originaria del texto decemviral, por lo que puede ser considerada como una glosa ciceroniana o preciceroniana que explica en clave difamatoria el término occentare. Cabe, en consecuencia, afirmar que Cicerón y Horacio - que se refieren a la difamación hablando respectivamente de occentare sive carmen condere y de mala carmina describere o condere-, o bien no habrían interpretado correctamente la locución o, como es más probable, son portavoces de la opinión común en su tiempo que consideraba a los mala carmina de las XII Tablas, no como fórmulas mágicas, sino ya como poemas difamatorios. Sólo en una época posterior, como se deduce del testimonio de Horacio, los cármenes difamatorios serían también definidos como mala carmina en el sentido de carmina maledica. 
esta noción está reservada a la ofensa física de la persona, al delito civil restringido al ámbito de las lesiones ${ }^{17}$. Será precisamente en el desarrollo que de esta noción amplia y genérica de la «iniuria» que haga el pretor donde encuentre el medio ordinario de represión los escritos difamatorios.

Esta noción de iniuria ${ }^{18}$ como delito privado específico va a desarrollarse de tal manera que, partiendo de la rudeza y materialismo

${ }^{17}$ Tampoco cabe plantear la posibilidad de que la noción de iniuria incluyese los escritos difamatorios (carmen famosum). A pesar del texto de las Sentencias de Paulo 5, 4, 6 que afirma Lege duodecim tabularum de famosis carminibus, membris ruptis et ossibus fractis, no parece que se pueda considerar que el delito de iniuria configurado en las XII Tablas recogiese los carmina famosa. El texto podría pues considerarse como una anticipación realizada en época postclásica.

De igual modo, no puede entenderse que la noción de iniuria decemviral comprendiera ningún tipo de difamación. El delito de iniuria en esta época está limitado a las lesiones físicas y, en concreto, a las ofensas personales penadas con los 25 ases, tal y como se recoge en la reconstrucciones de la tab.8.4, aquella ofensa física que no se concretaba en un membrum ruptum tab.8.2 o en un os fractum tab.8.3. Ahora bien, no se pena tanto la agresión física como la ofensa o agravio que ésta provoca por la connotación moral de la acción realizada non iure.

Este concepto de iniuria decemviral será objeto de una profunda evolución en época postdecemviral, incluyendo el membrum ruptum y el os fractum, hasta llegar a configurarse una noción de iniuria in corpus que comprenderá la ofensa física genérica a la que se atribuye una pena económica estimatoria y que en época clásica atribuirá al concepto técnico-jurídico de iniuria-contumelia, el ámbito de ofensa física junto al ámbito de ofensa moral que representa la contumelia.

La evolución mencionada se llevará a cabo a través de la intervención pretoria, mediante la promulgación del denominado edictum generalis de iniuriis aestimandis que unificará todas las lesiones bajo la noción de iniuria y a través de los edictos especiales que casuísticamente irán ampliando la noción de iniuria física a una concepción amplia de ofensa moral que será perfeccionada con elaboración de la jurisprudencia y terminará en la conocida noción de Labeón D. 47,10,1 pr. iniuria-contumelia.

${ }^{18}$ Respecto a la noción de «iniuria» y a la doctrina de principios de siglo XX.- HUVELIN, Les tablettes magiques et le droit romain, Études d'Historie du Droit Commercial Romain. Paris 1929. BECKMANN, Zauberei und Recht in Roms Frühzeit, Münster, 1923. FRAENKEL, Franz, Beckmann, Zauberei und Recht in Roms Frühzeit, Münster, 1923, Gnomon 1, 1925, pp. 185 ss. SMITH, The Law of libel at Rome, CQ.XLV, 1951 pp. 169 ss. LINDSAY, Defamation and the Law unter Sulla, CPh. XLIV 1949 , pp. 240 ss. HENDRICKSON, Verbal injury, magic, or erotic cosmus? CPh. XX, 1925 pp. 289 ss. DESPORT, Proyect d'une étude sur la notion de Carmenet son expression dans la literature latine, REL.20, 1942 pp. 40 ss. HENDRICKSON, Occentare Ostium bei Plautus, Hermes 61, 1926 pp. 78 ss. FRANK, Naevius and free spreech, AJPh. XLVIII 2 pp. 105 ss. RADIN, Freedom of Spreech in Ancient Athenes, AJPh. XLVIII 1, pp. 215 ss. RONCONI, «Malum carmen» e "malus poeta», Synteleia Arangio-Ruiz 2, Nápoles 1964 pp. 958-971.

Vid. al respecto la doctrina más actual: FERNÁNDEZ DE BUJÁN, A. Las nociones de infamia e ignominia Derecho Romano, Homenaje a Vallet de Goytisolo, vol. IV, Ma- 
primitivos recogidos en la Ley de las Doce Tablas ${ }^{19}$ y a través de una progresiva labor reformadora del pretor e interpretativa de jurisprudencia, se llegará a una espiritualización del ilícito ${ }^{20}$, a una desmaterialización del mismo que terminará en un concepto de iniuria ${ }^{21}$ comprensivo tanto de las ofensas físicas como morales dentro de las cuales tiene su lugar de difamación escrita.

drid 1998, pp. 313 ss. CASTILLO, M.S, Estudio sobre la casuística de las lesiones en la jurisprudencia romana, Madrid 1994, RodRíguez DíAz, E, A propósito de la actio iniuriarum, III Congreso Iberoamericano de Derecho Romano, León 6, 7 y 8 de febrero 1997, pp. 349 ss. HAGEMANN, M., Iniuria, Von den XII- Tafeln bis zur Justinianischen Kodifakation, Köln, Weimar, Wien, 1998. DE LAPUERTA MONTOYA, Estudio sobre el "edictum de ademptata pudicitia», Valencia 1999. FERNÁNDEZ PRIETO, La difamación en el Derecho romano, Valencia 2002. GUERRERO LEBRÓN, M., La protección jurídica del honor postmortem en Derecho Romano y en Derecho Civil, Granada 2002. GUERRERO LEBRÓN, M., La injuria indirecta en Derecho Romano, Colección Monografías de Derecho Romano Dirigidas por Pr. Dr. D. Antonio Fernández de

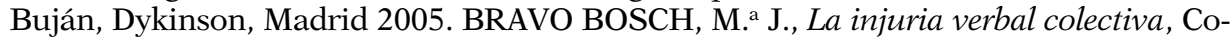
lección Monografías de Derecho Romano Dirigidas por Pr. Dr. D. Antonio Fernández de Buján, Dykinson, Madrid, 2007. MOLLÁ, S., "Relación entre iniuria e iniuria iudicis», en Liber amicorum Juan Miquel estudios romanísticos con motivo de su emeritazgo, Barcelona, 2006. MANFREDINI, Contributo allo studio dell'iniuria in etá repubblicana, Milano 1977; MANFREDINI, La Diffamazione verbale nel dirirtto romano, I, Età Repubblicana, cit., passim; MANFREDINI, L'iniuria nelle XII tavole. Intestabilis ex lege (Cornelia de iniuriis). Derecho romano de Obligaciones. Homenaje al Profesor José Luis Gener. Madrid 1994, pp. 799-809. MANFREDINI, Quod edictum autem praetorum de aestimandis iniuriis, en Illicito e pena privata in etá repubblicana (Atti convegno Copanello 1990), Napoli 1992. BALZARINI, «De iniuria extra ordinem statui» Contributi allo studio del diritto penale romano dell'età classica, Padua, 1983.

${ }^{19}$ Sobre la Ley de las XII tablas VOIGT. M, Die XII Tafeln Geschichte und system des Civil-und Criminal-Rechtes, wie Processes der XII Tafeln nebst deren Fragmenten. Zweiter Band: Das Civil-und Criminalrecht der XII Tafeln. Leipzig 1883. RICCOBONO, La lex XII Tabularium, Rivista di legislazione comparata, vol. I, 1904, pp. 5 y ss. RAGUSA, Le XII Tavole, Atenaeum, Roma 1925, pp. 63 y ss. (referencia a la tabla 8). APPLETON, Notre enseignement du droit romain ses ennemis et ses défauts, Mélanges de Droit Romain dédiés a Georges Cornil. Tomo I, Paris 1926, pp. 44 ss. CORNIL, Ancien Droit Romain. Le problèmedes origines, Paris 1930 pp. 78ss.

${ }^{20}$ BRAVO BOSCH, La injuria verbal colectiva, cit. p. 30

${ }^{21}$ Concepto de «iniuria» que manifiesta Labeón en D. 47, 10,1 pr. Ulpianus 56 ad ed.

Iniuria ex eo dicta est, quod non iure fiat: omne enim, quod non iure fit, iniuria fieri dicitur. hoc generaliter. specialiter autem iniuria dicitur contumelia. interdum iniuriae appellatione damnum culpa datum significatur, ut in lege aquilia dicere solemus: interdum iniquitatem iniuriam dicimus, nam cum quis inique vel iniuste sententiam dixit, iniuriam ex eo dictam, quod iure et iustitia caret, quasi non iuriam, contumeliam autem a contemnendo.

1. Iniuriam autem fieri labeo ait aut re aut verbis: re, quotiens manus inferuntur: verbis autem, quotiens non manus inferuntur, convicium fit. 


\section{ASPECTOS GENERALES DE LA INTERVENCIÓN PRETORIA EN LA ACTIO INIURIARUM}

La labor reformadora del pretor, ayudada por la jurisprudencia, actuó en dos direcciones: por un lado, ensanchando el concepto de iniuria para incluir toda lesión corporal o moral que tratase de minorar la estima de alguien ${ }^{22}$ causada de una persona a otra; y por otro lado, evaluando la pena pecuniaria en quantum aequum et bonum videbitur, de modo que la pena se adecua a la entidad de la ofensa, conforme a la estimación de la misma hecha por el actor —en caso de iniuria ordinaria - o por el magistrado - en los supuestos de iniuria más graves-, quedando a salvo la potestad del juez de emitir una condena ex bono et aequo adecuada a la justicia del caso concreto ${ }^{23}$. La importante labor del pretor fue precisamente la creación de acciones pretorias que van a reemplazar a las arcaicas, excesivamente rígidas, y en algunos casos caídas en desuso del ius civile. Estas acciones fueron creadas con fórmula aestimatoria para tipificar las conductas delictivas referidas a lesiones morales, si bien en principio el pretor no las va a considerar propiamente iniuriae ${ }^{24}$, sino que será más tarde la jurisprudencia la que generalice el concepto de iniuriae para integrar todos estos supuestos.

El desarrollo de la iniuria postdecemvial hasta la Lex Aebutia (a.130 a.C. Gell 16.10.8 y Gayo 4, 30) llevó a la ineficacia del talión por obra de la costumbre y la imposición de una pena pecuniaria determinada caso por caso por el juez ${ }^{25}$. De igual modo se configuró un concepto amplio de iniuria donde se comprenderían todos los delitos contra la persona física excepto el homicidio y las lesiones morales al que se extendió la aplicación de la pena variable determinada por el juez. Finalmente se concedió una actio testimoniada por Gelio 20,1,13 para fijar una aestimatio poenae a través de un iudicium recuperatorium ejercitable en todo supuesto de iniuria ${ }^{26}$.

Esta evolución se llevará a cabo a través de la intervención pretoria mediante la emanación de edictos que según WATSON ${ }^{27}$ comien-

\footnotetext{
${ }^{22}$ FERNANDEZ PRIETO, La difamación, cit. p. 65.

${ }^{23}$ FERNANDEZ PRIETO, La difamación, cit. p. 65., RODRIGUEZ DÍAZ, A propósito de la actio iniuriarum cit. p. 357.

${ }^{24}$ FERNANDEZ PRIETO, La difamación, cit. p 66; SANTA CRUZ TEIJEIRO Y D’ORS, «A propósito de los edictos especiales de iniuriis» en AHDE 1979. p. 653

${ }^{25}$ PUGLIESE, Studi sull iniuria, I, Milano 1941, pp. 81 ss.

${ }^{26}$ GELL, 20,1,13: praetores ...iniuria aestimandis recuperatories se dataros edixerunt...

${ }^{27}$ WATSON, The development of the praetor's edict, en JRS 60, 1970.
} 
zan a surgir a finales del siglo III a. C. Durante la primera centuria, los edictos sirven al pretor para modificar las sanciones de la ley de las XII Tablas y probablemente también para las leyes procedimentales, de manera que sólo indirectamente afectarán al derecho sustantivo. En la última década del siglo II a.C. los edictos del derecho pretorio comenzarán a transformar profundamente el ius civile aunque con la limitación de restringir los derechos del demandante en una acción civil y sólo a partir del 100 a.C se promulgarán edictos individuales que conceden acciones de derecho sustantivo totalmente nuevas, dentro de los cuales especial relevancia tendrán los referidos a la iniuria a los que nos referiremos brevemente.

Partamos, pues, del primer edicto en materia de iniuria que, según el orden edictal reconstruido por LENEL, fue el llamado edictum generalis de iniuriis aestimandis en el que conforme a la opinión general de la doctrina es el edicto en el que se subsumen todos los ataques fí$\operatorname{sicos}^{28}$ inferidos al demandante o a personas libres bajo su potestas $\mathrm{o}$ manus. Paralelamente se fueron sancionando por medio de otros edictos particulares, denominados especiales - edicto de convicium, de adtemptata pudicitia y ne quid infamandi causa fiat - distintos supuestos lesivos al honor de las personas. Finalmente y según las fuentes, la jurisprudencia extendió el primer edicto a todos los casos de iniuriae, denominándose así edictum generale, aunque dicha extensión es ampliamente debatida por la doctrina puesto que hasta el Edictum perpetuum se sigue manteniendo la presencia de tales edictos especiales.

Así, según MANFREDINI, se distinguen dos momentos fundamentales en el desarrollo de la actio iniuriarum respecto a la intervención pretoria: una fase inicial que se caracteriza por la emanación de una serie de edictos que tipifican figuras especiales de ofensas personales, pero que ninguno de ellos promete una acción típica sino que, en todos los casos, la fórmula concedida en la promesa edictal es la actio iniuriarum; y una segunda fase, ya en el régimen clásico de la iniuria - caracterizada por la sucesiva aplicación de la acción a todo hecho realizado «iniuriandi causa»-, en la que el pretor da relevancia jurídica a la noción técnica de iniuria elaboradas por la especulación de los prudentes en el sentido de contumelia ${ }^{29}$ produciéndose así la «espiritualización» del concepto de iniuria.

${ }^{28}$ DAUBE, Nocere and noxa, en The Cambridge Law Journal, 7, 1939 p. 23 y ss.; PLESCIA, The Development, cit. p. 280; en contra WATSON, The Law, cit. p. 249 ss. y MANFREDINI, Contributi cit. p. 12.

${ }^{29}$ MANFREDINI, Contributi cit. p. 183 y ss. 
La iniuria es una figura que evidencia claramente la relatividad de los institutos jurídicos en el tiempo, en el sentido de que no se puede valorar en abstracto la adecuación de la norma que la regula, sino que debe ser adaptada a las diferentes realidades sociales a las que va siendo aplicada. A este respecto Gayo 3, 223, nos informa de que la pena de 25 ases con la que se condenaba originariamente la iniuria respondía a las exigencias de las condiciones económicas de la época decemviral. Prontamente la norma se había ya manifestado insuficiente, en concreto, a partir de finales del siglo III a.C y, sobre todo, al final de la segunda guerra púnica, de manera que conforme afirma el propio Gayo 3, 224 nunc alio iure utimur fue modificada por el pretor. Los testimonios del jurista son confirmados por Gelio en el conocido fragmento 20,1 donde se narra el conocido episodio de Veracio que puso de manifiesto la ineficacia de las penas fijas establecidas y que impulsó a los pretores a intervenir fijando una acción para pedir una estimación pecuniaria por la iniuria sufrida.

Esta acción fue concedida por el pretor en un "probable» ${ }^{30}$ edictum generale y $^{31}$ constituye un paso decisivo en la historia del delito. Se discute en la doctrina si este edicto fue promulgado para reemplazar como parece deducirse del texto de Gelio $(20,1,13)$ sólo a la disposición de la tab. 8.4, o, si como opina la mayor parte de la doctrina, afectaba también a las normas de la tab 8.2 y 8.3. A este respecto quizá sea, siguiendo una lógica evolución, posible la concepción que defiende que, en origen, trató de reemplazar la pena fija de la tab. 8,4 por una condena in bonum et aequum concepta, pero que pronto fue extendida para cubrir las otras disposiciones referidas a las lesiones $^{32}$. Por otro lado, dicha acción correspondería al marido y al partefamilias por las injurias inferidas a su mujer, in manu o no, o a sus filiifamilias, pero no por las injurias ocasionadas a un esclavo que vendrían recogidas en otro edicto ${ }^{33}$. Por tanto, este edicto general se referiría tan sólo a las lesiones causadas a una persona libre para las que el pretor concedía una actio iniuriarum, denominación moderna con que se conoce a la actio de iniuriis aestimandis ${ }^{34}$.

\footnotetext{
${ }^{30}$ FUENTESECA. P., Derecho Privado Romano, Madrid, 1978, p. 326.

${ }^{31}$ PUGLIESE, Studi, cit. p. 96 ss.

32 PLESCIA, The Develop. cit. p. 280; BRETONE, Tecniche e ideologie, cit. p. 174, FERNÁNDEZ PRIETO, La difamacion, cit. p. 81. BRAVO BOSCH, La injuria, cit. p. 67-68.

${ }^{33}$ Respecto a la iniuria indirecta como estudio más reciente véase GUERRERO LEBRÓN, M, La injuria indirecta en Derecho Romano, Madrid, 2005.

${ }^{34}$ SCHULZ, Derecho Romano Clásico, trad. española Santa Cruz Teijeiro, Barcelona 1960, p. 568.
} 
La fecha de dicho edictum generale es discutida y fluctúa ${ }^{35}$ entre los autores que la sitúan desde el año 227 a.C hasta los que la retrasan hacia el 150 a.C. En todo caso, como afirma VON LUbTOW ${ }^{36}$, debió ser promulgado con anterioridad al 81 a.C, año en que se fecha la Lex Cornelia y según señala la doctrina más reciente la fecha posible del edicto de iniuriis aestimandis se centraría en la primera mitad del siglo II a.C.

Un nuevo paso en la evolución histórica del delito de iniuriae lo representa la gradual extensión a través de los «edictos especiales» de la actio iniuriarum aestimatoria con el fin de incluir dentro del ámbito de su aplicación no sólo las lesiones causadas al cuerpo de un hombre libre, sino también supuestos constitutivos de ofensas morales que afectaban a la fama o a la dignidad de la persona que, aunque no fueran considerados como constitutivos de iniuria propiamente dicha, eran protegidos por el pretor a través de la promesa de una acción relacionada y con una fórmula semejante a la de la actio iniuriarum, si bien en ocasiones nombrase unus iudex en vez de recuperatores.

Estos edictos, denominados «especiales», que junto al generale desarrollaron todo el derecho de la iniuria son los siguientes:

\section{a) Edictum de convicium}

Edicto que según se desprende de D. 47,10,15,2-14 (57 ad ed) rezaba: Ait praetor: "qui adversus bonos mores convicium cui fecisse cuiusve opera factum esse dicetur, quo adversus bonos mores convicium fieret: in eum iudicium dabo". El pretor concede con este edicto —en opinión de BRAVO BOSCH${ }^{37}$ - protección ante hechos considerados muy graves en una sociedad romana que era extremadamente sensible en todo aquello que afectaba a la buena reputación y

${ }^{35}$ Una parte de la doctrina -PLESCIA, The Develop, cit. p. 282 y DUCK-WORTH, The nature of roman comedy. A study in popular entertainment, Priceton 1952, p. 55de acuerdo con la fecha de la Asinaria de Plauto (205 a.C) que considera que indirectamente se refiere a la fórmula de la acción general, y teniendo en cuenta las fechas en las que mayor devaluación sufrió el as —según MATTINGLY 217 a.C y 209 a.C.- sugieren como fecha más adecuada finales del siglo III a.C en torno a los años 208-206 a.C. Otra parte de la doctrina considera excesivo situarlo en el siglo III a.C señalando la primera mitad del siglo II a.C -SANTA CRUZ/ A D'ORS, A propósito..cit. p. 655; DE LA PUERTA MONTOYA, Estudio sobre el edictum de adtempta, cit. p. 42; BRAVO $\mathrm{BOSCH}$, La injuria verbal, cit. p. 70.

${ }^{36}$ VON LUBTOW, Zum römischen, cit. p. 155.

${ }^{37}$ BRAVO BOSCH, La injuria, cit. p. 81 y ss. 
al honor, sancionado con severidad los insultos realizados en público. El motivo de dicha protección es el amparo del ciudadano romano que sufre una afrenta verbal, en público, proferida por un grupo de personas adversus bonos mores ${ }^{38}$. Por tanto, la difamación verbal oral tendrá su represión a través de este edicto.

\section{b) Edictum de adtemptata pudicitia ${ }^{39}$}

Viene referido por Ulpiano en D. 47,10, 15, 15-24 y Gayo 3,220 y castigaba los atentados al pudor de las mujeres honradas - matrefamilias - y de los jóvenes de ambos sexos que llevaban toga praetexta - praetextatus praetextatave- tipificando tres actos distintos a través de los cuales se entendía que se atentaba al pudor: cuando se le retiraba el acompañante a la fuerza (comitem abducere), o se cortejaba (appellare), o se seguía asiduamente (adsectari) a alguno de ellos por la calle contra las buenas costumbres.

\section{c) Edictum ne quid infamandi causa fiat}

Es recogido por Ulpiano en D. 47, 10, 15, 25-33 en los siguientes términos: Ait praetor: "ne quid infamandi causa fiat. si quis adversus ea fecerit, prout quaeque res erit, animadvertam» y castigaba cualquier cosa que alguien hubiese dicho o hecho con la intención de difamar a otra persona. Por tanto, incluiría las manifestaciones de la difamación escrita.

\section{d) Edictum de iniuriis quae servis fiunt}

Referido por Ulpiano en D. 47, 10, 15, 34-49 y 17, pr 2 y Paulo D. $47,10,15,16$ concede la acción al dueño por la fustigación de un esclavo y por la tortura ocurrida sin su orden —o extralimitándose de la misma- y contra las buenas costumbres, reservándose la facultad de concederla, previo conocimiento de causa, para otras ofensas ${ }^{40}$.

${ }^{38}$ D. 47, 10, 15, 6: Idem ait " adversus bonos mores» sic accipiendum non eius qui fecit, sed generaliter accipiendum adversus bonos mores huius civitatis.

${ }^{39}$ Sobre el edicto de ademptata pudicitia véase BRAVO BOSCH, "Algunas consideraciones sobre el edictum de adtemptata pudicitia,» en Dereito Revista Xuridica da Universidade de Santiago de Compostela 5 n. ${ }^{\circ} 2$ 1996; DE LAPUERTA MONTOYA, Estudio sobre el «edictum de adtemptata pudicitia», Valencia 1999.

${ }^{40}$ D. 47, 10, 15, 34: Praetor ait: "qui servum alienum adversus bonos mores verberavisse deve eo iniussu domini quaestionem habuisse dicetur, in eum iudicium dabo. item si quid aliud factum esse dicetur, causa cognita iudicium dabo». FERNÁNDEZ PRIETO, La difamación, cit. p. 100. 
e) Edictum de noxali iniurirarum actione

Previsto por Ulpiano en D.47, 10, 17, 3-941 ofrece al dueño del esclavo, en el caso de que éste haya inferido una iniuria y haya nacido una acción noxal contra aquel, la posibilidad de liberarse de su obligación de pagar la condena o abandonar la condena, haciendo azotar al esclavo culpable al arbitrio del juez dando así satisfacción a la víctima.

f) Edictum si ei, qui in alterius potestate erit, iniuria facta esse dicetur

Ulpiano alude a este edicto en D.47, 10, 17, 10-22 ${ }^{42}$ refiriéndose a aquél por el que el pretor retiene la facultad de conceder, con conocimiento de causa, acción al injuriado que está bajo la potestad de otro, cuando no estuviese presente aquél bajo cuya potestad está, ni hubiese procurador alguno que en este nombre ejercite la acción.

En el siglo I a.C estas cláusulas edictales fueron consideradas unitariamente y denominadas iniuria, noción donde se comprendía toda ofensa a la personalidad de un hombre libre, y la acción derivada de ella fue la actio iniuriarum.

\section{INTERVENCIÓN PRETORIA EN LA DIFAMACIÓN ESCRITA. CARMEN CONDERE- NE QUID INFAMANDI CAUSA FIAT}

A continuación centraremos nuestro estudio sobre la reforma pretoria en el ámbito de la difamación escrita partiendo del análisis del carmen conditum que consideramos en la introducción como parte de una glosa interpretativa de la tab. 8,1 b) atribuida a Cicerón y recogida por S. Agustín ${ }^{43}$, quizá la primera noción de poesía dra-

41 3. Quaedam iniuriae a liberis hominibus factae leves (non nullius momenti) videntur, enimvero a servis graves sunt: crescit enim contumelia ex persona eius qui contumeliam fecit. 4. Cum servus iniuriam facit, maleficium eum admittere palam est: merito igitur sicuti ex ceteris delictis, ita et ex hoc iniuriarum noxalis actio datur. sed in arbitrio domini est, an velit eum verberandum exhibere, ut ita satisfiat ei qui iniuriam passus est: neque erit necesse domino utique eum verberandum praestare, sed dabitur ei facultas praestare ei servum verberandum aut, si de eo verberibus satis non fiat, noxae dedendum vel litis aestimationem sufferendam

${ }^{42}$ Ait praetor: "si ei, qui in alterius potestate erit, iniuria facta esse dicetur et neque is, cuius in potestate est, praesens erit neque procurator quisquam existat, qui eo nomine agat: causa cognita ipsi, qui iniuriam accepisse dicetur, iudicium dabo»

${ }^{43}$ Conforme a la doctrina mágica se rechaza la idea de que la proposición «si occentavisset sive carmen condidisset quod infamiam faceret flagitiumve alteri» sea una 
mática, hasta llegar a reflejar todos los tipos de difamación escrita que, según las fuentes jurídicas y literarias, fueron reprimidos bajo el concepto del ilícito edictal ne quid infamandi causa fiat.

Según la opinión de los más autorizados partidarios de la interpretación difamatoria, la prohibición decemviral del carmina condere con el fin de infamar habría sido dirigida contra quien compone por escrito el carmen difamatorio destinado a ser recitado (occentatio). El carmen conditum no tendría nada que ver con una composición artística sino que pertenecería a aquel género que en la Roma de los Papas se llamaba pasquines ${ }^{44}$; por lo que la ausencia de una literatura en la época de las XII Tablas no debería constituir argumento contra la autenticidad de la tab.8.1, $\mathrm{b}^{45}$. Sin embargo esta interpretación del carmen conditum es contraria a lo manifestado por Cicerón y S. Agustín.

En los conocidos fragmentos de Sobre la ciudad Dios — donde el Santo discute en torno al distinto tratamiento de los griegos y los romanos frente a la libertad de difamar a los dioses y los hombres, y en los cuales él cita fragmentos de Sobre la república de Cicerón como prueba del hecho de que ab antiquo los romanos no podían difamar libremente a los hombres porque existía la norma sobre la «occenta-

correcta cita del precepto decemviral, y sin embargo se accede a aquélla según la cual, desde sive (en el sentido de id est) hasta el final, nos encontramos frente a una glosa ciceroniana o preciceroniana que explica en clave difamatoria el término occentare. Este término sólo previsto por los decemviros, sería «interpretado» de conformidad con aquellas tendencias glosográficas entre las cuales estaría el texto de Festo, sv. Occentassint (L. 190)

MASCHKE, Die Persön..., cit., pp. 13 ss., considera la locución sive carmen condidisset como una paráfrasis o glosa explicativa de occentavisset, opinión a la que se adhiere BECKMANN, Zauberei..., cit., pp. 56 ss., quien habla de una interpretación culta y particular de Cicerón sobre el origen histórico de la norma sobre la occentatio, interpretación que ser remontaría a la época preciceroniana, sería asumida por éste y, por tanto, difundida posteriormente en época clásica. HUVELIN, La notion..., cit., pp. 73 ss., partiendo de que Cicerón ha comprendido mal, considera la cita ciceroniana, salvo con algún leve retoque, como correspondiente al original, incluida la mención del carmen condere quod infamiam faceret flagitiumve alteri.

De igual modo son planteados otros aspectos linguísticos y estilísticos más específicos respecto al texto de Cicerón recogido por S. Agustín para afianzar la interpretación de la glosa: así se habla, por una parte, de que el uso de los términos flagitium e infamia con el significado abstracto de escándalo y difamación se corresponde con una época más tardía, presentando en la antigüedad decemviral un significado concreto sensiblemente distinto. Por otra parte, se afirma el hecho de que la cita ciceroniana no presenta los trazos estilísticos en los que comúnmente se reconoce un precepto auténticamente decemviral.

${ }^{44}$ Así FRAENKEL, rec a Beckmann, cit., p. 192; 198 ss.

${ }^{45}$ En este sentido MOMIGLIANO, rec. a Robinson, p. 121. 
tio sive carmen condere»- resulta de modo claro que tanto Cicerón como Agustín ${ }^{46}$ creen que tal norma hubo de ser dictada por la necesidad de reprimir la poetarum licentia y precisamente la licencia de los poetas de teatro ${ }^{47}$. S. Agustín asegura que los romanos no han conocido el despreciable fenómeno de la difamación lanzada por los poetas sobre la escena, puesto que has sido disipada por la dura disposición decemviral relativa a la occentare sive carmen condere y, por tanto, siempre apoyándose en Cicerón, explícitamente atribuye a tal norma el objeto de impedir la probra y maledicta de los poetas ${ }^{48}$.

Está, de este modo, fuera de dudas que Cicerón y Agustín consideran que el precepto fue dirigido contra la licencia de los poetas y que el carmen conditum fuese la poesía dramática; por ello es curioso que cuantos dan plena fe a la cita del precepto proyectada por Cicerón-Agustín, tomen después distancia de dichos autores y se refieran al carmen conditum como pasquines y no como poesía teatral.

Por otra parte esta concepción del carmen conditum parece históricamente fundada. Los términos condere ${ }^{49}$, conditus, atribuidos a carmen o versus, expresan la idea de la creación artística, designan un producto, meditado y no improvisado, de ingenio poético. Elocuente

${ }^{46}$...Quid Romani veteres de cohibenda poetica licentia sanserint, quam Graeci, deorum secuti iudicium liberam esse voluerunt; ... Graeci... apud quos fuit etiam lege concessum ut quod laedere vellet comoedia, de quo vellet nominatim dicere;... dicit (Cicerón) deinde alia et sic concludit hunc locum ut ostendat veteribus displicuisse Romanis vel laudari quemquam in scaena vivum hominem vel vituperari (Aug. Civ.2,9); ... Scipio, laudas hanc poetis Romanis nagatam esse licentiam, ut cuiquam opprobrium infligerent Romanorum...ut linguam maledicam in cives tuos exercere poetae etiam lege prohiberentur, et in deos tuos securi tanta convicia nullo senatore, nullo censore, nullo principe, nullo pontifice prohibente iacularentur? Indignum videlicet fuit ut Pautus aut Naevius Publio et Gn. Scipioni aut Caecilius M. Cantoni malediceret et dignum fuit ut Terentius vester flagitio Iovis optimi maximi adulescentium nequitiam concitaret... ? (Aug.civ.2,12)

${ }^{47}$ ZIEGLER, M.Tullius Cicero, De re publica, Lipsiae, 1964 p. 112 ss.

${ }^{48}$ At romani, sicut in illa de re publica disputatione Scipio gloriatur, probris et iniuriis poetarum subiectam vitam famamque habere noluerunt, capite etiam sancientes, tale carmen condere si quis auderet

${ }^{49}$ Los significados fundamentales de condere parecen ser: abscondere y constituere (Non. p. $349 \mathrm{M}=$ p. 376 L) Paulo Diácono indica como más antiguo el primero y como de más tardía formación los significados de conscribere, facere, componere e instruere. En el liber glossarum, Goetz II, p. 108, condere/componere es entendido como poihsai. Fuera de dudas, el término condere, referido a carmen (ver. VIRG. Ecl.10,50, a poema (CIC. Att.1,16,15), oratio (PLIN. nat, 5,112), volumen (v. PLIN nat. 6,55), evidencia el aspecto constructivo, creativo del producto literario, no designa sólo la forma escrita. El término conscribere, que sólo Paulo Diácono usa para definir los significados de condere, referido a carmen, no quiere decir escribir un carmen, sino componer un carmen por escrito. 
al respecto es el difundido uso del término inconditus para designar toda forma de carmen no rigurosamente correspondiente a las leyes métricas o producido por la tradición sacral y épica y no atribuible a un autor de profesión. Las nenias ${ }^{50}$, los cármenes triunfales ${ }^{51}$, los versos fesceninos ${ }^{52}$ cuando nacen espontáneamente en las fiestas campestres y nupciales, son denominados carmina incondita o incompta.

A este respecto Livio, apoyandóse en un documento oficial, define como conditum al carmen que fue compuesto por Livio Andrónico en el 207 a. $C^{53}$ y califica, de igual modo, como conditum al carmen que fue compuesto en el 200 a.C por el poeta P. Licinius Tegula ${ }^{54}$. Asimismo tal y como se puede deducir de estos testimonios y de otros, el carmen conditum, además de compuesto por escrito, era destinado a la divulgación oral: eran 27 vírgenes, en dos de los casos anteriormente citados, quienes recitaban públicamente los carmina, entonándolos en el curso de una procesión ${ }^{55}$.

Muy probablemente la primera forma de carmen conditum, como producto poético conscientemente elaborado por un autor, de forma artística aunque sea rudimentariamente, deba buscarse en la historia de la poesía dramática.

El locus classicus para la historia del teatro y de la literatura en general, es el texto de Livio 7, 2, 1-12 $2^{56}$, en esencia confirmado por Va-

${ }^{50}$ Del lat. nenĭa).

1. f. Composición poética que en la Antigüedad gentílica se cantaba en las exequias de alguien.

2. f. Composición que se hace en alabanza de alguien después de muerto.

NON, p. 145 M. (=p. 212 L)

${ }^{51}$ LIV. 4, 20, 2; 7, 10, 13;10, 30, 9; ioci inconditi: 5, 49, 7;7, 38, 3; DION, 7, 32

${ }^{52}$ LIV, 7,2,5; VERG. georg, 2,386.

${ }^{53}$ LIV, 27, 37, 7.

${ }^{54}$ LIV, 31,12,10.

${ }^{55}$ LIV. 27, 37, 13; 31, 12, 9. La primera composición de tales carmenes es atribuida a Valerio Máximo $(2,4,4)$ a los años 365-364 y entendida como el evento con el que se habría iniciado los ludi scaenici. Este episodio no es mencionado por Livio que, en 7,2, narra los mismos hechos pero tomando la fuente de Valerio Máximo, bastante probablemente Varrón [Para todos PRÈAUX, «Ars ludicra. Aux origines du théâtre latin» en AC 32 (1963) p. 63; PASOLI, «Satura dramática e satura letteraria», en Vichiana 1 (1964 p. 4].

${ }^{56}$ II. et hoc et insequenti anno C. Sulpicio Petico C. Licinio Stolone consulibus pestilentia fuit. eo nihil dignum memoria actum, [2] nisi quod pacis deum exposcendae causa tertio tum post conditam urbem lectisternium fuit; [3] et cum uis morbi nec humanis consiliis nec ope diuina leuaretur, uictis superstitione animis ludi quoque scenici-noua res bellicoso populo, nam circi modo spectaculum fuerat-inter alia caelestis irae placamina instituti dicuntur; [4] ceterum parua quoque, ut ferme principia omnia, 
lerio Máximo ${ }^{57}$. Livio afirma que después de los ludi sine carmine que fueron introducidos desde la Etruria, para vencer a la peste del 364 a.C, los jóvenes de Roma se pusieron a imitar (o parodiar) tal espec-

et ea ipsa peregrina res fuit. sine carmine ullo, sine imitandorum carminum actu ludiones ex Etruria acciti, ad tibicinis modos saltantes, haud indecoros motus more Tusco dabant. [5] imitari deinde eos iuuentus, simul inconditis inter se iocularia fundentes uersibus, coepere; nec absoni a uoce motus erant. [6] accepta itaque res saepiusque usurpando excitata. uernaculis artificibus, quia ister Tusco uerbo ludio uocabatur, nomen histrionibus inditum; [7] qui non, sicut ante, Fescennino uersu similem incompositum temere ac rudem alternis iaciebant sed impletas modis saturas descripto iam ad tibicinem cantu motuque congruenti peragebant. [8] Liuius post aliquot annis, qui ab saturis ausus est primus argumento fabulam serere, idem scilicet-id quod omnes tum erant-suorum carminum actor, [9] dicitur, cum saepius reuocatus uocem obtudisset, uenia petita puerum ad canendum ante tibicinem cum statuisset, canticum egisse aliquanto magis uigente motu quia nihil uocis usus impediebat. [10] inde ad manum cantari histrionibus coeptum diuerbiaque tantum ipsorum uoci relicta. [11] postquam lege hac fabularum ab risu ac soluto ioco res auocabatur et ludus in artem paulatim uerterat, iuuentus histrionibus fabellarum actu relicto ipsa inter se more antiquo ridicula intexta uersibus iactitare coepit; unde exodia postea appellata consertaque fabellis potissimum Atellanis sunt; [12] quod genus ludorum ab Oscis acceptum tenuit iuuentus nec ab histrionibus pollui passa est; eo institutum manet, ut actores Atellanarum nec tribu moueantur et stipendia, tamquam expertes artis ludicrae, faciant.

${ }^{57}$ VAL. MAX 2, 4, 4: Nunc causam instituendorum ludorum ab origine sua repetam. C. Sulpico Petico C. Licinio Stolone consulibus intoleranda uis ortae pestilentiae ciuitatem nostram a bellicis operibus reuocatam domestici atque intestini mali cura adflixerat, iamque plus in exquisito et nouo cultu religionis quam in ullo humano consilio positum opis uidebatur. itaque placandi caelestis numinis gratia conpositis carminibus uacuas aures praebuit ad id tempus circensi spectaculo contenta, quod primus Romulus raptis uirginibus Sabinis Consualium nomine celebrauit. uerum, ut est mos hominum paruula initia pertinaci studio prosequendi, uenerabilibus erga deos uerbis iuuentus rudi atque inconposito motu corporum iocabunda gestus adiecit, eaque res ludium ex Etruria arcessendi causam dedit. cuius decora pernicitas uetusto ex more Curetum Lydorumque, a quibus Tusci originem traxerunt, nouitate grata Romanorum oculos permulsit, et quia ludius apud eos hister appellabatur, scaenico nomen histrionis inditum est. paulatim deinde ludicra ars ad saturarum modos perrepsit, a quibus primus omnium poeta Liuius ad fabularum argumenta spectantium animos transtulit, isque sui operis actor, cum saepius a populo reuocatus nocem obtudisset, adhibito pueri ac tibicinis concentu gesticulationem tacitus peregit. atellani autem ab Oscis acciti sunt. quod genus delectationis Italica seueritate temperatum ideoque uacuum nota est: nam neque tribu mouetur <actor> nec a militaribus stipendiis repellitur. Los tres últimos puntos de la narración liviana están sustancialmente presentes también en Valerio Máximo. En cambio los primeros dos puntos son totalmente distintos. Valerio Máximo escoge en la composición y en la audición popular de los carmina, el primer ensayo de ludi scenici, en cambio Livio lo considera con la venida de los ludiones etruscos. La evolución inmediatamente posterior es descrita por Valerio Máximo como consistente en el hecho de que la iocabunda iuventus romana habría añadido la gestualidad — rudi atque incomposito motu corporum - a los venerabilibus erga deos verbis (esto es, habrían parodiado los carmina) y esta circunstancia habría ofrecido motivos para hacer venir un ludius de Etruria, cuya agradable agilidad place a los romanos sólo por la novedad. Livio en cambio, que no acepta el rito de los carmina y 
táculo añadiendo inconditi versus inter se, de carácter jocoso (iocularia). El uso de estos espectáculos se difunde y los protagonistas toman el nombre de histriones.

El posterior desarrollo tuvo lugar cuando cesó el cambio alterno del verso semejante al fescenino (incompositum ac rude) y ya los vernaculi artificies representan sátiras realizadas modis (con medida métrica), con un cantus descriptus (ordenado, conditus) y con el movimiento añadido al canto. Después de algunos años Livio Andrónico, probablemente en el $240^{58}$ a.C, osó traer de la satura una fabula como enredo. Perdiendo este género, el risus y el solutus iocus, los jóvenes retoman inter se more antiquo ridicula intexta versibus iactitare y nace los exodia para asimilarse a las atelanas ${ }^{59}$.

que identifica la llegada de los ludi scenici con el espectáculo de los ludiones etruscos, centra la segunda fase sobre la imitación que la iuventus hizo de los danzadores etruscos y sobre el cambio de iocularia [consistentes en versus inconditi $(7,2,5)$ en burlas de verso inculto y rudo - incompositum ac rude - semejante a aquel fescenino] en el que el gesto estaba en acuerdo con la voz. Sin duda el testimonio de Livio, desde el punto de vista de la dramaturgia es más atendible. Pero admitiendo que el placamen de los carmina hubiera existido y que de éste se haya burlado la juventud, es sin duda más correspondiente a la verdad que a la sátira dramática se haya pervivido cuando a la iuventus, después de la llegada de los ludiones etruscos, «urbanizó» el uso de los fesceninos agrestes $\mathrm{y}$, añadiéndoles la danza, dando vida a una forma de dramaturgia mixta de palabras y danza, imprentada a la desacralización, a lo grotesco, a la sátira. La iuventus, entendida como clase de edad, urbana y atada a las armas, se abandonaba inter se a tales formas espontáneas e improvisadas de divertimentos porque en esto legitimada por ancestrales exigencias sociales de desacralización, de envilecimiento de los acontecimientos importantes y serios (MOREL, La iuventus, cit. 214 ss.). La llamada sátira dramática (esto es, la tercera fase de evolución de la dramaturgia) no fue otra cosa que la conversión en forma de arte la Fescennina iocatio de los iuvenes [BOYANCÈ, A propos de la sature dramatique, en REA 34 (1932) P. 14; CÈBE, La satura, cit. p. 26 ss., quien afirma que la danza preexistía a la llegada de los ludiones etruscos]. MANFREDINI, La diffamazione, cit. p. 97.

${ }^{58}$ Esta es la opinión Varroniana (CIC, Brut. 72: Atqui hic Livius [qui] primus fabulam C. Claudio Caeci filio et $M$. Tuditano consulibus docuit anno ipso ante quam natus est Ennius, post Romam conditam autem quarto decumo et quingentesimo, ut hic ait, quem nos sequimur. est enim inter scriptores de numero annorum controversia. Accius autem a $Q$. Maxumo quintum consule captum Tarento scripsit Livium annis xxx post quam eum fabulam docuisse et Atticus scribit et nos in antiquis commentariis invenimus; GELL.17,21,42: Annis deinde postea paulo pluribus quam uiginti pace cum Poenis facta consulibus <C. $>$ Claudio Centhone, Appii Caeci filio, et M. Sempronio Tuditano primus omnium L. Liuius poeta fabulas docere Romae coepit post Sophoclis et Euripidis mortem annis plus fere centum et sexaginta, post Menandri annis circiter quinquaginta duobus.

59 (Del lat. atellāna [fabŭla], de Atella, Atela, ciudad de los oscos, célebre por su anfiteatro y sus representaciones graciosas). adj. Se dice de una pieza cómica de los latinos, semejante al entremés o sainete). 
De estos textos dos aspectos son relevantes. El primero se refiere a la marcada diferencia establecida por Livio entre el ludus de la juventud romana (el carácter improvisado y rudo de sus burlas; su naturaleza de entretenimiento de grupo, inter se) y la connotación profesional, artística que asume la sátira dramática, también está compuesta de poemas y danzas pero cultivada en forma de arte y representada al pueblo por los vernaculi artifices ${ }^{60}$.

Claramente se enfrentan dos distintos modos de entender y practicar uno mismo uso: por la iuventus se trata de un ludus, de un iocus solutus ${ }^{61}$, para los artífices se convierte en una profesión artística. Se contraponen dos concepciones: aquélla del carmen satírico inconditum, lícito porque «ridiculiza grandes cosas» y es el medio para restablecer el equilibrio del destino y aquélla del carmen satírico conditum, compuesto por poetas de profesión con deliberado objeto de sátira y destinado a la pública recitación. Este último, precisamente porque está fuera de la función que lo legitimaba, y no siendo ya un iocus, no va a ser solutus ${ }^{62}$.

${ }^{60}$ Estos aspectos los encontramos también en MOREL, La iuventus, p. 237. Sobre la forma de arte asumida por la sátira dramática (y en esto sólo consistiría su diferencia de la fescennina iocatio, acompañada de la danza, practicada por la juventud) cfr. DUCKWORTH, The nature of Roman Comedy, Pricenton, 1952 p. 6; CEBÈ, La Satura, p. 31 ss., que habla de una forma mejorada de la sátira, alcanzada en torno al 360 .

${ }^{61}$ Impunidad de la irrisión, maledicencia lícita, este es significado que al iocus solutus atribuye COCCHIA, La letteratura latina anteriore all'influencia ellenica, III, Nápoles, 1925, p. 248.

${ }^{62}$ Según MOREL, La iuventus, cit. pp. 239 ss., la clase de los jóvenes se habría alejado deliberada de esta forma de dramaturgia en el momento en el que ésta fue cultivada por profesionales; asumiendo la forma de entretenimiento artístico destinado al público, la iuventus - clase militar y por esto, conservadora- se habría retractado escandalizada y sólo más tarde habría retomado la antigua mos, cuando esto es toma vida los exodia que se mezclaron con las atelanas; y por el hecho de que tal género era fruto de la improvisación y porque desacralizaba el teatro serio, oficial, de las fabulae de enredo, no incurría en los rigores de las leyes y, por ello, fue definido por un status favorable y especial, para el actor de atelanas, sobre lo que informa Livio $(7,2,12)$, Valerio Máximo $(2,4,4)$, Festo sv. personata (L.238): «Une pièce de Névius porte ce titre, parce qu'elle est la première, à ce que l'on croit, qui fut jouée par des acteurs masqués. Mais comme elle fut jouée bien des années après l'époque où les acteurs comiques et tragiques avaient introduit l' usage des masques, il est plus vraisemblable que, par suite du manque d'acteurs, cette nouvelle pièce fut jouée par les Atellans, qui sont proprement appelés personati, parce qu'on n'a pas le droit de les contraindre à ôter leur masque sur la scène, ce que les autres histrions ne peuvent se refuser à faire». Todo ello parece perfectamente plausible; en particular la indiscutible relación entre el antiguo uso de la fescennina iocatio por la iuventus y los exodia de época más avanzada avalan la idea de que, en la concepción romana del tiempo, se concibe una contraposición neta entre carmen satírico inconditum y carmen satírico conditum, entre ludus y ars (o profesionalización), entre legitimación y favor acordado al primero y prohibición y hostilidad al segundo. MANFREDINI, sin embargo, se 
El segundo punto se relaciona con el testimonio de Livio según el cual, en los orígenes como en la evolución posterior, los artifices eran actores suorum carminum, de modo que autor y actor se identifican en la misma persona.

Conforme a estas observaciones se podría identificar el carmen conditum como sátira dramática ${ }^{63}$ - de reconocido carácter de poesía, de arte desacralizado, profanador, burlesco y profesionalmente cultivado - con la forma más antigua de carmen conditum a la que podría congruentemente referirse una ley que vetase el carmen conditum difamatorio. Asimismo la identificación que se propone coincide con cuanto afirman Cicerón y Agustín sobre la referencia de tal ley a la poesía teatral.

Sin embargo el fragmento de Livio así como los textos de Horacio $^{64}$, Virgilio ${ }^{65}$ y Tibulo ${ }^{66}$ han sido criticados ${ }^{67}$ y de ellos se ha afir-

inclina a pensar que el abandono por parte de los jóvenes de la sátira dramática se debe no tanto por un espontáneo rechazo cuanto el temor de medidas represivas. En el fragmento liviano no está claro la relación entre iuventus y actores de profesión; los primeros vernaculi artifices que tomaron el nombre de histriones podrían ser de los iuvenes (así MOSEL, op. p. 242) y fue probablemente la huella de la remoción de las tribus y la supresión del stipendium (además probablemente, de otras medidas coercitivas entre las que se encuentra la verberatio) que disuaden a la iuventus de cultivar de forma profesional, el carmen conditum, el público espectáculo, aquel género de poesía mimada, profanadora y burlona, que era lícita sólo en cuanto fuese un ludus inter se, un divertimento espontáneo que absolviera a una función de naturaleza mágica o religiosa.

${ }^{63}$ MANFREDINI, La diffamazione... cit. p. 100

${ }^{64}$ Horacio, epist. 2,1,139-157:

Agricolae prisci, fortes paruoque beati, condita post frumenta leuantes tempore festo 140 corpus et ipsum animum spe finis dura ferentem, cum sociis operum pueris et coniuge fida Tellurem porco, Siluanum lacte piabant, floribus et uino Genium memorem breuis aeui.

Fescennina per hunc inuenta licentia morem uersibus alternis opprobria rustica fudit, libertasque recurrentis accepta per annos lusit amabiliter, donec iam saeuos apertam in rabiem coepit uerti iocus et per honestas ire domos impune minax. Doluere cruento dente lacessiti, fuit intactis quoque cura condicione super communi; quin etiam lex poenaque lata, malo quae nollet carmine quemquam describi; uertere modum, formidine fustis ad bene dicendum delectandumque redacti. Graecia capta ferum uictorem cepit et artes ${ }^{65}$ VIRG, geor, 2, 385 ss. intulit agresti Latio;

${ }^{66}$ TIB, $2,1,51$. 
mado que no corresponden con la realidad romana sino que transponen la tradición del teatro griego transmitida por Varrón o por Accio $^{68}$.

Según Horacio, en las raíces de la literatura poética y dramática de Roma se encuentran los fesceninos rústicos que mantienen su trato de iocus hasta que se transformaron apertam in rabiem contra las honestae domus (los nobles) y por ello se emanó una ley que vetaba y sancionaba representar a cualquiera (describi) con un malum carmen, siendo así que la formido fustis llevó al bene dicere.

Una relación más explícita entre la ley prohibitoria del malum carmen condere y la sátira dramática la encontramos en Evancio ${ }^{69}$ cuyo testimonio nunca se haya puesto en la discusión sobre la represión del malum carmen conditum. Tanto en Evancio. De com.

${ }^{67} \mathrm{El}$ fragmento de Horacio, en la literatura, ha sido particularmente discutido en el ámbito del problema de los orígenes de la poesía dramática y en lo referido a la represión del carmen difamatorio en las XII tablas. En el primer ámbito, contra la tendencia a negar alguna relación entre el testimonio de Horacio y la sátira (LEO, Livius und Horaz, cit. p. 63; KROLL, sv. satura, cit.col. 198), se proclama la plena atendibilidad e importancia en la reconstrucción y comprensión de las más antiguas formas de poesía indígena no de imitación, entre las que se incluye también la así llamada sátira dramática (por todos véase ROSTOGNI, Storia I, cit, 63 ss.). En la discusión sobre la represión de la poesía difamatoria dispuesta por los decemviros, el fragmento de Horacio no es reconocido como plenamente atendible por ninguna de las opiniones ya expuesta. Los sostenedores de la tendencia difamatoria afirman que el poeta documenta de modo atendible la existencia de una ley (que sería aquella de las XII Tablas), que reprimiría la poesía difamatoria, pero que ciertamente yerra cuando refiere la locución malum carmen que pertenecería a la otra disposición que se refería a los sortilegios (por todos FRAENKEL, rec. a BECKMANN). Por otra parte los partidarios de la tendencia mágica afirman que Horacio está en la verdad cuando cita el malum carmen pero yerra cuando interpreta la norma decemviral, que se refería, en clave difamatoria, mostrando en este aspecto seguir la interpretación ciceroniana que probablemente se remonta a la investigación filológica-anticuaria de época prevarroniana (BECKMANN, Zauberei, cit. p. 66). Nadie, salvo MANFREDINI ha pensado que Horacio, esté expresándose en términos no rigurosamente técnicos, haya querido referirse a una ley, que recoja la poesía difamatoria que no tenía nada que ver con las XII Tablas.

${ }^{68}$ Principalmente LEO, Varro und die satire, en Hermes 2, 1889. p. 77 ss., ahora en Ausgewählte kleine Schriften, Roma 1960,I; Livius und Horaz über die Vorgerschichte des römischen Dramas, en Hermes 30 1904, p. 63 ss.; HENDRIKSON, The Dramatic Satura and the Old Comedy at Rome, en AJPh 15 1894, p. 1 ss.; A prevarroniam Chapter of Roman Literary History, en AJPh 19 1898, p 285 ss.; KROLL, sv. satura, en RE II, A, 1 col. 197 ss.; VAN ROOY, Studies in Classical Satire and Related Literary Theory, Leyde 1966 p,. 33 ss.

${ }^{69}$ Sobre este enigmático erudito que vivió en la primera mitad del siglo IV cfr. SCHANZ, HOSIUS, Röm. Lit, IV, 1, 1914, p. 179 ss. 
II, 3-4 (K. p. 63 s.) $)^{70}$ como en el posterior fragmento donde esta idea es mejor sustentada (Euanth. De com. II, 5-6 (K. p. 64) ${ }^{71}$ se trata del fenómeno típicamente romano de la sátira dramática. Desde el punto de vista de su contenido de vitiis civium, ésta es entendida como el correspondiente romano de la comedia ática. Antes de llegar in suspicionem civium potentibus era un iocus agrestes y tuvo un cambio en el genus stilo carminis hasta que incluye el uso de describere in peius de los hechos que se refieren a los más importantes ciudadanos. Ése es el carmen sine ullo titulo propri nominis que los poetas abandonaron amordazados por la ley ne quisquam in alterum carmen infame componerte.

Por tanto de la lectura conjunta de los testimonios de CicerónAgustín $^{72}$, Horacio ${ }^{73}$ y Evancio resulta que claramente la tradición romana unía la antigua ley sobre el malum carmen al fenómeno de la licencia de los poetas teatrales. La combinación de las palabras de Livio, Horacio y Evancio no deja duda sobre la existencia de una sólida tradición, probablemente recogida de Varrón en el de poetis, según la cual la ley sobre el malum carmen conditum se refería expresamente a la sátira dramática. Y puesto que sabemos por Livio que la llegada de la sátira dramática tuvo lugar en torno al 364 a.C cuando fueron instituidos los juegos escénicos, la disposición sobre el malum carmen o infame carmen conditum no puede haber sido contemplada por los decemviros.

${ }^{70}$ EV. De com. II, 3-4 (K. p. 63 s.): et eponomatoV dicta est: arcia idcirco quia nobis pro nuper cognitis vetus est, ep onomatoV autem quia inest in ea velut historica fides verae narrationis et denominatio civium, de quibus libere describebatur, etenim per priscos poetas non ut nunc ficta penitus argumenta sed res gestae a civibus palam cum eorum saepe qui gesserant nomine decantabantur; dique ipsum suo tempore moribus multum profuit civitas, cum unusquisque caveret culpam, no spectaculo ceteris estitisset et domestico probo. sed cum poetae licentius abuti stilo et passim laedere ex libidine coepissent plures bonos, ne quisquam in alterum carmen infame componerte lata lege siluere.

${ }^{71}$ EV. de com. II: et hinc deinde aliud genus fabulae id est satyra sumpsit exordium, quae a satyris, quos in iocis semper ac petulantiis deos scimus esse, vocitata est: etsi (alii ductum) aliunde nomen prave putant. haec satyra igitur eiusmodi fuit, ut in ea quamvis duro et velut agreste ioco de vitiis civium tamen sine ullo proprii nominis titulo carmen esset. quod item genus comoediae multis offuit poetis, cum in suspicionem potentibus civium venissent, illorum facta descripsisse in peius ac deformasse genus stilo carminis. quod primus Lucilius novo conscripsit modo, ut poesin inde fecisset, id est unius carminis plurimos libros. hoc igitur quod supra diximus malo (esto es la ley contra el carmen difamatorio, mencionada antes) coacti omitiere satyram aliud genus carminis ... repperere poetae...

${ }_{72}$ CIC, rep. 4,12, referido por AGU, civ 2,9.

${ }^{73}$ HOR, epist. 2,1,139-157 
Si no fue contemplada por los decenviros nos debemos preguntar cuándo fue reprimido por primera vez ese malum o infame carmen conditum. Parece que la respuesta se puede encontrar en la lectura de Horacio $^{74}$ (y su comentarista Porfirio ${ }^{75}$ ) y Evancio, seguidores de la tradición que unía la represión del malum o infame carmen conditum a la sátira dramática, desarrollada en época posterior al 364 a.C, puesto que hablan genéricamente de «una ley» que habría dispuesto tal represión y no la de las XII Tablas. Así se puede atribuir la primera represión del malum carmen conditum a una misteriosa ley emanada (en época sucesiva al 364 a.C y antes del 264 a.C) para reprimir la licencia verbal de los autores-actores de sátiras dramáticas. Se impone entonces el deber de saber si tal tradición es razonable y si esto fuera cierto habría que plantearse qué contenido se encerraba dentro del genérico enunciado de una prohibición del malum carmen condere (Cicerón-Agustín), de malo carmine describere (Horacio), de carmen infame componere (Evancio), cuya variabilidad y diversas formas de expresión podían denotar un carácter no técnico-jurídico del mismo.

A esta cuestión ha intentado contestar MANFREDINI, planteando - creemos acertadamente- la vía de la coerción. El argumento es el siguiente, según Suetonio ${ }^{76}$, Augusto retira a los magistrados la coerción — que había sido considerada lícita por una "antigua ley»contra los histriones, salvo en escena y durante los juegos, y conforme a lo expuesto por Tácito ${ }^{77}$ la disposición de Augusto consistiría en haber sustraído a los magistrados el derecho de usar la vara contra los histriones. Según este autor es importante subrayar la mención de una vetus lex que habría restituido a los magistrados el derecho de coerción contra los histriones, consistente en el ius virgarum, en la verberatio. La lex vetus nos trae a la mente los más antiguos histriones de los que las fuentes han conservado memoria, esto es, los vernaculi artificies que según Livio transformaron los inconditus versus Fescenninus en el carmen conditum de la sátira dramática y que tomarían el nombre de histriones.

${ }^{74}$ Horacio en epist. 2,1,152 ss., habla de lege, sin ninguna referencia a las XII Tablas; en sat. 2,1,81 hace decir al jurista Trebacio que la ignorancia de la sancta leges, de las que deriva que si mala condiderit in quem quis carmina ius est iudicium, puede dañarlo. Sólo si entendemos las tabulae citadas en el v. 86, que se diluyeran en risa de bona carmina, como las XII Tablas, se puede pensar que Horacio relacionase el malum carmen con la ley de los decemviros.

${ }^{75}$ PORPH. en Hor, sat. 2,2,81 y epist.2,1,148.

${ }^{76}$ SUET, Aug. 45: coercitionem in histriones magistratibus omni tempore et loco lege vetere permissum, ademit praeterquam ludis et scaena.

${ }_{77}$ TAC, ann. 1,77 
Así, de este modo, se debe pensar en la antigua ley (que en el lenguaje corriente, por comodidad, era designada como referente al malum o infame carmen conditum) como una ley que sólo indirectamente rozaba el fenómeno de la difamación verbal. Probablemente se limitaba a conferir a los magistrados el derecho de coercere, sine provocatione, a través de la verberatio, a los histriones (en aquel tiempo autores y actores de sus carmina teatrales) que hubiesen difamado desde el palco escénico. Y así, según Horacio, a través de la ley sobre el malum carmen y precisamente en virtud de la formido fustis, se habría pasado del maledicere al benedicere ${ }^{78}$.

A la luz de todo lo expuesto hasta ahora parece que se pueda fundadamente asumir que el problema de la difamación verbal en Roma se pone de manifiesto con la llegada de la poesía teatral, de manera que en la más antigua intervención represiva de la difamación verbal de la que las fuentes encontramos las siguientes connotaciones: 1) sólo la poesía dramática recitada no extemporánea pero producida por poetas de profesiones, era considerada (el carmen inconditum no pudo ser malum porque es un ludus, una iocatio); los primeros poetas son autores de teatro que normalmente también son actores, entregados a las recitaciones a otros de su poesía dramática, por tanto, scribae histrionesque; 2) sólo la difamación proferida oralmente y en público, esto es, desde el palco escénico, era relevante, y 3) se trataba probablemente de una intervención inspirada en intereses de clase y dirigida a la protección de los principes civitatis.

Esa vetus lex no es entendida como una ley criminal que habría tipificado un crimen, dispuesto una sanción y previsto una represión ordinaria en las formas que entonces regían para el crimen legitimum, sino que los indicios parecen que acreditan la idea de que la represión de la poetarum licentia entrase en la esfera de la coercitio $^{79}$. A la luz de las palabras ciceronianas y de las categorías jurídicas que la ciencia romanística ha recabado, se puede afirmar que el ilícito del malum carmen no fue entendido como un crimen bajo una represión

${ }^{78}$ HOR, epist. 2,1,152.

${ }^{79}$ En el conocido fragmento de CICERÓN, leg. 3, 6 se dice: magistratus nec oboedientem et innoxium civem multa vinculis verbebusve coherceto, ni par maiorve potestas populusve prohibesset, ad quos provocatio esto. quom magistratus iudicassit inrogassitve, per populum multae poenae certatio esto. En el fragmento es distintamente individualizado el doble plano sobre el que se desarrolla la función represiva de los ilícitos penales: aquel de la represión extraordinaria que se avala de la libre coerción de los magistrados y de las sanciones que estos pueden conminar, entre los que la verberatio (en los límites impuestos de las leyes sobre la provocatio y por la apelación de la par maiorve potestas), y aquel de la iurisdictio o iudicatio. 
ordinaria, una iudicatio, sino como acto de desobediencia que podía ocasionar intervenciones coercitivas por parte de los magistrados, en general en los límites de la provocatio, pero libres de ésta si se trataba de la verberatio. De este modo el poeta que faltaba a la licentia verborum era un nec oboediens et innoxius civis o probrum.

Este es el término técnico que designa el ilícito reprimido por los censores ${ }^{80}$ y la frecuencia con el que es usado para designar la difamación verbal atestigua que el ilícito podría entrar en la jurisdicción censoria ${ }^{81}$. Al respecto es importante las normas, citadas por Livio y Valerio Máximo ${ }^{82}$, según las cuales los histriones movetur tribu y a militaribus stipendiis repellitur. La primera norma, atribuida por Cicerón-Agustín a los romani veteres ${ }^{83}$, está expresamente adscrita por estos autores al regimen forum de los censores y especialmente en el único lugar donde se trata carmen conditum y de la poetarum licentia. Léase en consecuencia el texto de Cicerón, rep. 4,10 referido por Aug. civ 2,1384.

Por todo ello parece fundado afirmar que el ilícito del malum carmen conditum no fue entendido, en su origen, ni como crimen (así sucederán sólo en época augusta) ni como delictum (que ocurrirá, en el desarrollo del siglo II a.C, a través de la concesión de la actio iniuriarum ex edicto de convicio acordada por el pretor contra la difamación nominativa en la escena). Tal ilícito fue entendido como probrum, reprimido por los censores, o como un acto de desobediencia que podía también ocasionar, entre otros medios coercitivos, la verberatio sine provocatione, por parte de los magistrados: cónsules, con auxilio de los tresviri capitales, pretores, sin duda también los tribunos y ediles ${ }^{85}$.

${ }^{80}$ CIC, leg, 3,7; SALL, Cat. 23; PLIN, nat. 18,11. Sobre el control de la libertad de palabra ejercitado ROBINSON, «Censorship in Republican Drama», en CJ 42, 1946, p. 147 ss.

${ }^{81}$ FERNÁNDEZ DE BUJÁN.A, Las nociones de infamia e ignominia...cit. p. 321 ss.

${ }^{82}$ LIV, 7, 2, 12; VAL.MAX, 2, 4, 4.

${ }^{83}$ Agustín en civ. 2,13 donde reproduce el fragmento de Cicerón referido en el texto, habla genéricamente de romani pero en civ. 2,9 expresamente se refiere a romani veteres. El mismo Cicerón, en la digresión sobre la poetarum licentia a la que pertenece el fragmento relativo a la jurisdicción censoria, cita explícitamente a los romani veteres (de rep. 4,12).

${ }^{84}$ AUG. civ 2,13: cum artem ludicram scaenamque totam in probro ducerent, genus id hominum non modo honore civium reliquorum carere sed etiam tribu moveri notatione censoria voluerunt.

${ }^{85}$ En supuestos de vigilancia sobre los lugares públicos y en el ejercicio de la cura ludorum sabemos que éstos estaban autorizados con el ius virgarum, quizá especialmente contra los histriones y que no eran insensibles a los insultos verbales (GELL. 10, 6; SUET. Tib.2; VAL. MAX. 8,1.) 
Si bien se puede considerar que en los inicios el poder represivo de los magistrados (coerción) era plenamente discrecional, tanto por lo que se refiere al medio de punición (la multa no superior a los límites legales, el encarcelamiento, la verberatio o la nota de infamia) como por lo que respecta a la apreciación de la difamación, en esta última dirección, bien pronto debieron establecerse los criterios de valoración a los que tendrían que someterse los magistrados en el concreto ejercicio de su poder represivo ${ }^{86}$.

Cicerón ${ }^{87}$, como conocemos por San Agustín en el único lugar donde se discute sobre la norma del occentare sive carmen condere y la licencia de los poetas dramáticos, afirma que veteribus displicuisse Romanis vel laudari quemquam in scaena vivum hominem vel vituperari (a los romanos antiguos les desagradaba que una persona viva fuera alabada o vituperada en la escena). La regla es atribuida a los veteres Romani y expresamente referida a la poesía dramática. Su formulación, que de forma taxativa circunscribe el veto de laudare o vituperare vivum hominem sobre la escena, legitima la idea de que sobre la escena los muertos se pudiesen alabar o denigrar ${ }^{88}$ y que fuera del palco escénico, fuese quizá generalmente tolerado que se loase y se despreciase verbalmente también a los vivos. La regla en cuestión es probable que fuera emanada, como punto de referencia para la apreciación de la conducta de los poetas, para el práctico ejercicio de la represión magistratual de la poetarum licentia.

Lo mismo se puede decir de la regla que prohibía la nominatio in scaena de alguien. Sobre su antiguo origen y la originaria pertenencia al fenómeno de la difamación verbal desde la escena, según el parecer

${ }^{86}$ Respecto a la provocatio ad populum como límite a esa coerción del magistrado véase FREZZA Corso di Storia del Diritto romano, Roma 1954, p. 74.;BONFANTE Storia del Diritto romano I,4. ${ }^{\circ}$ ed. Milán 1958 p. 57; GAUDEMET Institutions de l'antiquité París 1967 p. 320;NICOLET Le métier de citoyen dans la Rome républicanaine, París 1976 p. 429; SANTANLUCÍA Época Repubblicana: lo sviluppo del prucesso criminale e le leggi de provocatione, en Lineamenti di storia del diritto romano Milán 1979 p. 104. GROSSO Monarchia, provocatio e processo popolare «Studi De Francisci» II, Milán 1956, p. 6 y ss. Provocatio per la perduellio p. 218; RODRIGUEZ-ENNES La provocatio ad populum como garantía fundamental del ciudadano frente al poder coercitivo del magistrado en época Republicana Studi Biscardi IV. Milano 1983, pp. 73-114.

${ }^{87} \mathrm{CIC}$, rep. 4,12, referido por AGU, civ 2,9.

${ }^{88}$ Sobre la existencia de esta regla en época avanzada y con un ámbito de aplicación más amplio que al menos comprendiese también las obras escritas, hay algún importante testimonio. Lucilio ataca ferozmente a L. Lupus muerto; Juvenal $(1,170 \mathrm{ss})$ toma partido por atacar en su poesía sólo a los difuntos (GÉRARD, Juvenal et la réalité contemporaine, Paris 1976 p. 456). Tácito después parece citar una regla de más remota costumbre cuando afirma que maxime solutum et sine obtrectatore fuit prodere de iis quos mors odio aut gratiae exemisset (ann 4,35). 
de MANFREDINI ${ }^{89}$, no existen dudas. La Rhetoria ad Herennium ${ }^{90}$, a propósito de la difamación perpetrada sobre la escena contra los poetas Accio y Lucilio, nos documenta la existencia de una prohibición de compellere, laedere nominatim in scaena de aliquem nominari. Terencio calla cuidadosamente los nombres de sus detractores a los que, desde la escena, lanza molestos dicterios y un fragmento de una tragedia de Accio, recogido por Nonio, recita: primores provocavit nominans.

De este modo se puede considerar que la primera noción de malum carmen conditum vendría referida a la sátira dramática. Pero será en la época de finales de la República cuando el fenómeno de la difamación verbal se incremente de tal manera que la proliferación de ésta lleve a la necesidad de la intervención pretoria en la represión de los escritos infamantes.

El período comprendido entre los Gracos y Augusto es considerado como aquél en el que la difamación oral y escrita era practicada amplia e impunemente y con gran difusión. Se prestan como ejemplo, como testimonios directos, las sátiras de Lucilio que contienen ásperas invectivas incluso dirigidas, nominativamente, contra los ilustres hombres de la política, los cármenes de Catulo contra César y las oraciones in Cicerone e in Sallustium. Se subrayan las noticias relativas al florecimiento de una riquísima «literatura de la invectiva», en poesía y en prosa, con un fin no sólo político sino también personal. Se añade la tradición anecdótica relativa a la dicacitas (cavillitas, urbanitas, ioci, dicta) de la época ciceroniana y posterior, de la que los lugares clásicos son Valerio Máximo, Quintiliano y Macrobio ${ }^{91}$.

No obstante, frente a ese desarrollo junto a la actio iniuriarum ex edicto de convicio (fechado en el II a.C) con la que se reprimiría el insulto, permanece inmutable el tradicional aparato represivo - durante tiempo arbitrario y discrecional- de la coercitio y de la jurisdicción censoria.

Las obras de Cicerón y las narraciones historiográficas de este período no dejan lugar a duda sobre el hecho de que en las legitimae disceptationes era admitida la más franca libertad de crítica personal que rozaba la calumnia y que igual libertad de crítica personal era reconocida en las relaciones personales de los primores y de aquellos que con los primores, tenían potentes lazos de clientela.

\footnotetext{
${ }^{89}$ MANFREDINI, La diffamazione, cit. p. 125

${ }^{90}$ Rhet. Her. 1, 14, 24; 2, 13, 19.

${ }^{91}$ VAL.MAX. 6, 2; QUINT. 6, 3 y MACR. Sat. 2, 1-16.
} 
Sin embargo, el hecho verdaderamente nuevo que se produce en esta época, propiciado y favorecido por las mismas reglas y concepciones legitimantes de la difamación oral ${ }^{92}$ y que revuelve, con sus manifestaciones peculiares, las reglas prohibitivas surgidas expresamente en relación a esta última, está representado por la difamación escrita ${ }^{93}$.

Empieza a surgir una verdadera proliferación de las cartas dirigidas contra la élite. Horacio ${ }^{94}$ dirá refiriéndose al pueblo mutavit mentem populus levis et colest /scribendi studio; pueri patresque severi /fronde comas victi curant et carmina dictam. La tendencia a la literatura científica, ya manifestada en época catoniana, se intensifica y convierte en símbolo de Estado. Pero también los géneros tradicionalmente hostiles como la poesía son cultivados. Es conocido que Q. L. Catulus, cónsul en el 102 a.C, se deleitaba con poesía erótica y promovía un cenáculo literario ${ }^{95}$. Sila escribió de las saturikai kwmwdiai $^{96}$. G. B. Strabón, cónsul en el 88 a.C, fue poeta trágico, precedido por $\mathrm{C}$. Titius que vivió en época luciliana y cuya pertenencia a la clase política se puede deducir de una suasio legis Fanniae bastante ingeniosa y de otras oraciones de las que Cicerón subraya los fragmentos picantes y la urbanidad. También escribieron versos, como es conocido, Catón el menor ${ }^{97}$, Cicerón, César y Augusto ${ }^{98}$. Hasta Servio el jurista escribía versos licenciosos ${ }^{99}$.

Se difunde el uso, ya practicado por S.S. Galba, cónsul del 144 a.C, y Q.C. Metellus, cónsul del 143 a.C, de divulgar por escrito los

${ }^{92}$ La represión ordinaria del insulto (maledictum) data de la época relativamente reciente (final del segundo siglo) y deriva del fenómeno de la theatralis licentia. No el insulto escrito sino aquel oral, es el primeramente considerado; no toda forma de insulto sino sólo aquel que presenta notables caracteres de publicidad y que es, probablemente, nominativo. Otras connotaciones (su carácter de urbanitas, de iocus, el hecho de que de era dirigido a un noces... etc.) podían considerarlo no punible incluso si era pronunciado in coetu y/o cum vociferatione puesto que no era adversus bonus mores, nota esencial para su represión.

${ }^{93}$ Escasa atención es prestada en la literatura a la profunda diferencia, en las diversas formas de difamación verbal, entre difamación oral y escrita en la experiencia romana de la época tardorepublicana. Alguna observación en SMITH, The Law cit. p. 172 , quien en la escasa circulación de los escritos encuentra el motivo de la impunidad acordada a Lucilio.

${ }^{94}$ HOR, epist. 2, 1, 108 ss

${ }^{95}$ HOR, epist. 2, 1, 108-270.

${ }^{96}$ BARDON, La littérature latine inconnue, I, Paris, 1952, p. 115 ss.

${ }^{97}$ PLUT, Cat. min, 7, 2.

${ }_{98}$ Para la producción poética de Cicerón, César y Augusto véase MOREL, Fragmenta poetarum Latinorum, Stuttgard 1927.

${ }^{99}$ OV. tr, 2, 441; PLIN. epist. 5.3.5. 
textos de las oraciones políticas y judiciarias ${ }^{100}$. La licitud de la difamación, siempre reconocida en las legitimae disceptationes donde encuentran su lugar las orationes (discursos), no venía a menos cuando estas últimas eran redactadas por escrito y publicadas; y gracias a esto, nos han llegado algunos ejemplos paradigmáticos de la licencia verbal que se practicaba en el género oratorio como los discursos ciceronianos pro Caelio, in Verrem o las Philippicae.

Pero también en las relaciones privadas, estrictamente personales o políticas, y en las relaciones mundanas se asume el uso de las cartas. La tradicional inclinación a la burla, a la batuta cáustica, la venenosa habladuría, se apodera de las formas poéticas de la poesía jámbica y epigramática e inventa un juego de masacre a golpe de versos difamatorios de los que tenemos los testimonios más elocuentes en la poesía neotérica, en los epigramas de Catulo (87-54 a.C.) contra César ${ }^{101}$, de Calvo contra César y Pompeyo ${ }^{102}$ y en los jámbicos de Bi-

${ }^{100}$ CIC. Brut. 81-82: [81] Nam et A. Albinus, is qui Graece scripsit historiam, qui consul cum L. Lucullo fuit, et litteratus et disertus fuit; et tenuit cum hoc locum quendam etiam Ser. Fulvius et Numerius Fabius Pictor et iuris et litterarum et antiquitatis bene peritus; Quinctusque Fabius Labeo fuit ornatus isdem fere laudibus. nam Q. Metellus, is cuius quattuor filii consulares fuerunt, in primis est habitus eloquens, qui pro L. Cotta dixit accusante Africano; cuius et aliae sunt orationes et contra Ti. Gracchum eita est in C. Fanni annalibus.

[82] Tum ipse L. Cotta est veterator habitus; sed C. Laelius et P. Africanus in primis eloquentes, quorum exstant orationes, ex quibus existumari de ingeniis oratorum potest. sed inter hos aetate paulum his antecedens sine controversia Ser. Galba eloquentia praestitit; et nimirum is princeps ex Latinis illa oratorum propria et quasi legituma opera tractavit, ut egrederetur a proposito ornandi causa, ut delectaret animos aut permoveret, ut augeret rem, ut miserationibus, ut communibus locis uteretur. sed nescio quomodo huius, quem constat eloquentia praestitisse, exiliores orationes sunt et redolentes magis antiquitatem quam aut Laeli <aut> Scipionis aut etiam ipsius Catonis; itaque exaruerunt, vix iam ut appareant.

${ }^{101}$ Cármen 57:

Pulcre convenit improbis cinaedis, Mamurrae pathicoque Caesarique. nec mirum: maculae paris utrisque, urbana altera et illa Formiana, impressae resident nec eluentur: morbosi pariter, gemelli utrique, uno in lecticulo l erudituli ambo, non hic quam ille magis vorax adulter, rivales socii puellularum. pulcre convenit improbis cinaedis.

Y poema 93: $\quad$ Nil nimium studeo, Caesar, tibi velle placere nec scire, utrum sis albus an ater homo.

102 SUET. Iul, 49; Pudicitiae eius famam nihil quidem praeter Nicomedis contubernium laesit, graui tamen et perenni obprobrio et ad omnium conuicia exposito. omitto Calui Licini notissimos uersus: 
baculo contra César y Octaviano ${ }^{103}$. Pero no se puede creer que sólo los grandes protagonistas fuesen el centro del fenómeno ${ }^{104}$. También éstos descendían al combate de la pulla mordaz y de la respuesta. Octaviano, además de los lascivi versus contra Antonio y su mujer ${ }^{105}$, es-

\author{
Bithynia quicquid \\ et pedicator Caesaris umquam habuit.
}

praetereo actiones Dolabellae et Curionis patris, in quibus eum Dolabella 'paelicem reginae, spondam interiorem regiae lecticae, 'at Curio 'stabulum Nicomedis et Bithynicum fornicem' dicunt. missa etiam facio edicta Bibuli, quibus proscripsit collegam suum Bithynicam reginam, eique antea regem fuisse cordi, nunc esse regnum. quo tempore, ut Marcus Brutus refert, Octauius etiam quidam ualitudine mentis liberius dicax conuentu maximo, cum Pompeium regem appellasset, ipsum reginam salutauit. sed C. Memmius etiam ad cyathum + et ui + Nicomedi stetisse obicit, cum reliquis exoletis, pleno conuiuio, accubantibus nonnullis urbicis negotiatoribus, quorum refert nomina. Cicero uero non contentus in quibusdam epistulis scripsisse a satellitibus eum in cubiculum regium eductum in aureo lecto ueste purpurea decubuisse floremque aetatis a Venere orti in Bithynia contaminatum, quondam etiam in senatu defendenti ei Nysae causam, filiae Nicomedis, beneficiaque regis in se commemoranti: 'remoue,' inquit, 'istaec, oro te, quando notum est, et quid ille tibi et quid illi tute dederis.' Gallico denique triumpho milites eius inter cetera carmina, qualia currum prosequentes ioculariter canunt, etiam illud uulgatissimum pronuntiauerunt: Gallias Caesar subegit, Nicomedes Caesarem: ecce Caesar nunc triumphat qui subegit Gallias, Nicomedes non triumphat qui subegit Caesarem.

y schol. en LUC. 7, 726.

103 TAC. Ann. 4, 34. Cornelio Cosso Asinio Agrippa consulibus Cremutius Cordus postulatur novo ac tunc primum audito crimine, quod editis annalibus laudatoque $M$. Bruto C. Cassium Romanorum ultimum dixisset. accusabant Satrius Secundus et Pinarius Natta, Seiani clientes. id perniciabile reo et Caesar truci vultu defensionem accipiens, quam Cremutius relinquendae vitae certus in hunc modum exorsus est: 'verba mea, patres conscripti, arguuntur: adeo factorum innocens sum. sed neque haec in principem aut principis parentem, quos lex maiestatis amplectitur: Brutum et Cassium laudavisse dicor, quorum res gestas cum plurimi composuerint, nemo sine honore memoravit. Titus Livius, eloquentiae ac fidei praeclarus in primis, Cn. Pompeium tantis laudibus tulit ut Pompeianum eum Augustus appellaret; neque id amicitiae eorum offecit. Scipionem, Afranium, hunc ipsum Cassium, hunc Brutum nusquam latrones et parricidas, quae nunc vocabula imponuntur, saepe ut insignis viros nominat. Asinii Pollionis scripta egregiam eorundem memoriam tradunt; Messala Corvinus imperatorem suum Cassium praedicabat: et uterque opibusque atque honoribus perviguere. Marci Ciceronis libro quo Catonem caelo aequavit, quid aliud dictator Caesar quam rescripta oratione velut apud iudices respondit? Antonii epistulae Bruti contiones falsa quidem in Augustum probra set multa cum acerbitate habent; carmina Bibaculi et Catulli referta contumeliis Caesarum leguntur: sed ipse divus Iulius, ipse divus Augustus et tulere ista et reliquere, haud facile dixerim, moderatione magis an sapientia. namque spreta exolescunt: si irascare, adgnita videntur.

${ }^{104}$ Tenemos noticias de epigramas de Bibaculo contra L. Orbinius (SUET. Gramm. 9); de Cinna contra Hermógenes Tigelinus (CIC. fam, 7,24,1. Varrón (rust.3,2,17).

${ }^{105}$ MART. 11,20:

Caesaris Augusti lascivos, livide, versus sex lege, qui tristis verba Latina legis: 
cribía Fescennini contra Polión y éste agudamente decía que no podía rescribire contra quien lo podía proscribire, como triumviro ${ }^{106}$. Se trata ciertamente de una pauta que significativamente ilumina la nueva realidad de los tiempos: el licet respondere se convierte en licet rescribere; y era un escrúpulo excesivo aquel de Polión, si es verdad, como parece, que Octaviano, no sólo por triumviro sino también por augusto, prefería el rescribire a las medidas coercitivas ${ }^{107}$. Así es probable que al criminosissinius liber de A. Caecina y a los carmina maledicentissima de Pitholaus ${ }^{108}$, César ${ }^{109}$ hubiese dado ocasión o hubiese respondido con sus propios carmina y no se hubiese limitado a soportar civili animo. Catón el menor lanzó yambos contra quien le ha-

"Quod futuit Glaphyran Antonius, hanc mihi poenam

Fulvia constituit, se quoque uti futuam.

Fulviam ego ut futuam? Quod si me Manius oret

pedicem? faciam? Non puto, si sapiam.

'Aut futue, aut pugnemus' ait. Quid quod mihi vita

carior est ipsa mentula? Signa canant!»

Absolvis lepidos nimirum, Auguste, libellos, qui scis Romana simplicitate loqui.

106 MACR. Sat. 2, 4, 21.

${ }^{107}$ SUET. Aug. 51:...faciam sicat Aelianus et me linguam habere, plura enim de eo loquar...; 56: locis quoque quorundam invidiosis aut petulantibus lacessitus, contradixit edicto.

${ }^{108}$ SUET. Iul. 75. Además de por los poetae novi César fue atacado, en el plano personal, por escrito, también por Curio padre (CIC. Brut. 218), por A. Caecina y Pitholaus (SUET. Iul. 75, por Cicerón en ciertas cartas y por Bibulus con edictos (SUET. Iul. 49).

${ }^{109}$ SUET. Iul. 75.: Moderationem uero clementiamque cum in administratione tum in uictoria belli ciuilis admirabilem exhibuit. denuntiante Pompeio pro hostibus se habiturum qui rei publicae defuissent, ipse medios et neutrius partis suorum sibi numero futuros pronuntiauit. quibus autem ex commendatione Pompei ordines dederat, potestatem transeundi ad eum omnibus fecit. motis apud Ilerdam deditionis condicionibus, cum, assiduo inter utrasque partes usu atque commercio, Afranius et Petreius deprehensos intra castra Iulianos subita paenitentia interfecissent, admissam in se perfidiam non sustinuit imitari. acie Pharsalica proclamauit, ut ciuibus parceretur, deincepsque nemini non suorum quem uellet unum partis aduersae seruare concessit. nec ulli perisse nisi in proelio reperientur, exceptis dum taxat Afranio et Fausto et Lucio Caesare iuuene; ac ne hos quidem uoluntate ipsius interemptos putant, quorum tamen et priores post impetratam ueniam rebellauerant et Caesar libertis seruisque eius ferro et igni crudelem in modum enectis bestias quoque ad munus populi comparatas contrucidauerat. denique tempore extremo etiam quibus nondum ignouerat, cunctis in Italiam redire permisit magistratusque et imperia capere; sed et statuas Luci Sullae atque Pompei a plebe disiectas reposuit; ac si qua posthac aut cogitarentur grauius aduersus se aut dicerentur, inhibere maluit quam uindicare. itaque et detectas coniurationes conuentusque nocturnos non ultra arguit, quam ut edicto ostenderet esse sibi notas, et acerbe loquentibus satis habuit pro contione denuntiare ne perseuerarent, Aulique Caecinae criminosissimo libro et Pitholai carminibus maledicentissimis laceratam existimationem suam ciuili animo tulit. 
bía arrebatado a la novia ${ }^{110}$. Lenaeus acerbissima satura leceravit Salustio que había definido Pompeyo como "probo" de hechos pero de ánimo desvergonzado ${ }^{111}$. Sin ninguna duda nos encontramos frente al ejercicio de un licet rescribere ${ }^{112}$.

En este movimiento circular de dicho mordaz y respuesta se defiende toda una literatura de invectiva (de ataque y de defensa), que en la época de las guerras civiles es vastísima y que se convierte en un instrumento de propaganda política. Ésta cultiva también géneros específicos como la fingida oratio que se imagina tener lugar ante un tribunal o frente al senado (son ejemplos la célebres in Ciceronem e in Sallustium, aquella ciceroniana in Pisonem que ocasionó una respuesta, del mismo tipo, por parte de Pisón ${ }^{113}$, o aquélla que Cicerón escribióo ${ }^{114}$ en respuesta a Curión padre) $)^{115}$, o usa géneros ya reconocidos como las epistulae de las que bien conocidas son aquellas cargadas de veneno intercambiadas entre Antonio y Octaviano; o bien consistentes en meros escritos de invectiva sin pretensiones artísticas, como probablemente aquellos de V. Messala contra Antonio y el escrito de este último de sua ebrietate ${ }^{116}$.

Pero la literatura difamatoria, por su naturaleza y por el modo en el que se desarrolla, en la época que consideramos, la difusión de los escritos excepcionalmente - al menos hasta que se desarrolló la editorial y la figura del librarius y se practicó la publica recitatio- llega-

${ }^{110}$ PLUT. Cat. min. 7, 2.

111 SUET. gramm. 15.: Lenaeus, Magni Pompei libertus et pene omnium expeditionum comes, defuncto eo filiisque eius schola se sustentavit; docuitque in Carinis ad Telluris, in qua regione Pompeiorum domus fuerat, ac tanto amore erga patroni memoriam extitit, ut Sallustium historicum, quod eum oris probi, animo inverecundo scripsisset, acerbissima satyra laceraverit, lastaurum et lurconem et nebulonem popinonemque appellans, et vita scriptisque monstrosum, praeterea priscorum Catonisque verborum ineruditissimum furem. Traditur autem puer adhuc Athenis surreptus, refugisse in patriam, perceptisque liberalibus disciplinis, pretium suum retulisse, verum $o b$ ingenium atque doctrinam gratis manumissus.

112 SEN. contr, 10, praef. 8.

113 CIC. ad Q. fr. 3,1,11.

${ }^{114}$ CIC. Att. 3,12,2.

${ }^{115}$ Un ejemplo más es el recogido en ASCON. Tog. c. 91 s. C, del que se conoce que L. Lucceius escribió contra Catalina algunas oraciones en las que se le reprobaba incesto y adulterio.

${ }^{116}$ CHARIS. gramm. I. 104, 18 K. (de antonii statuis) ; I, 146, 34 s (de vectigalium Asiae constitutione) ; I, 129, 7 (contra Antonii litteras). La naturaleza bastante vulgar y burlona de tales escritos se puede reconocer de las palabras de PLIN. nat. 33, 50. Entre los escritos difamatorios dirigidos a Antonio, además de los citados, se recuerdan: contra maledicta Antonii, de A. Pollio (CHARIS, gramm. I. 80, 2), y una sátira escrita por Trebonius en el 43 (CIC. fam. 12, 16, 3). 
ba al vulgo. Producida como fruto de los primores y por quien tenía con ellos vínculos de clientela no salía del ambiente y, por tanto, no publicándose, no presentaba, en principio, ningún peligro. No obstante, la divulgación de las obras escritas tenía lugar.

Cuando se trataba de un liber $^{117}$, de una obra de autor, la máxima publicidad de la obra se realizaba cuando un librarius promovía la redacción en numerosos ejemplares y la pública venta en las librerías. Pero aquella editorial del librero que da impulso al comercio de libros es una figura relativamente reciente. El primero que se conoce es Atico (amigo de Cicerón a quien dedica sus famosas Cartas). Por esto es oportuno considerar que hasta este momento la publicación de las obras escritas era privada: los autores consignaban el manuscrito, redactado en una o dos copias, a personas de cultura, normalmente amigos importantes, de los que se esperaba extraer útiles consejos y consideraciones. De las copias cedidas podían ser extraídas, autorizadas o no, nuevas trascripciones. En esto parece consistir el hecho de edere (edicere, publicare, etc) librum ${ }^{118}$.

${ }^{117}$ Entre las acepciones del término liber, en el significado trasladado de charta scripta, asumido per metonimiam materiae (FORCELLINI, shv. signif. II, 1) está claramente documentada, ya en los escritos ciceronianos, aquella de obra escrita de autor, dividida al menos en partes (libri o volumina FORCELLINI, shv. signif. II, 2). Para la historia del libro, del material de escritorio y de la edición, se vean entre otras las investigaciones clásicas de BIRT, Das antike Buchwesen, Berlin 1882; DZIATZKO, sv. Buch, en RE III, 1, col. 939 ss; KLEBERG, Buchandel und Verlagswesen in der Antike, Darmstadt 1967.

${ }^{118}$ MARROU, «La tecnique de l'edition à al epoque patristique», en VChr.3, $1949 \mathrm{p}$ 208 ss sostiene que el fenómeno de la edictio implicaba sólo eventualmente y no necesariamente la presencia del librarius y que consistía simplemente en la trascripción que un tercero hacía de un manuscrito recibido del autor; en contra DZIATZKO, sostiene que se estaría ante un publicare, divulgare, ekdidonai, vulgare, emitiere, edere sólo cuando interviene el librarius que dirija las copias para vender en la librería. A favor de la primera opinión se debe argumentar el fragmento de Cicerón Att. 8,9,1 (quod me magno animi motu perturbatum putas, sum equidem sed non tam magno quam tibi fortasse videor. levatur enim omnis cura cum aut constitit consilium aut cogitando nihil explicatur. lamentari autem licet illud quidem totos dies; sed vereor ne nihil cum proficiam etiam dedecori sim studiis ac litteris nostris. consumo igitur omne tempus considerans quanta vis sit illius viri quem nostris libris satis diligenter, ut tibi quidem videmur, expressimus. tenesne igitur moderatorem illum rei publicae quo referre velimus omnia? nam sic quinto, ut opinor, in libro loquitur Scipio, 'Vt enim gubernatori cursus secundus, medico salus, imperatori victoria, sic huic moderatori rei publicae beata civium vita proposita est, ut opibus firma, copiis locuples, gloria ampla, virtute honesta sit. huius enim operis maximi inter homines atque optimi illum esse perfectorem volo.') que debe leerse conjuntamente con Att. 8,2,1 donde la publicación de un escrito parece que tuviese lugar cuando el mismo era dado a otro para que lo transcribiese (mihi vero omnia grata, et quod scripsisti ad me quae audieras et quod non credidisti quae digna diligentia mea non erant et quod monuisti quod sentiebas. ego ad Caesarem 
La publicación privada de las obras escritas permite al autor, en principio, controlar la circulación. No obstante el control de la difusión del liber podía huir de la mano del autor si se prodigaban y se divulgaban fuera del ambiente nuevas copias, con desconocimiento o contra la voluntad del autor mismo ${ }^{119}$.

La incertidumbre y los peligros del fenómeno se vieron en el caso de Valerius Valentinus, quien, además de haber compuesto con pseudónimo la conocida Lex Tappula ${ }^{120}$, parece que también escribió una obra con puntos autobiográficos tan indecentes y comprometedoras que, cuando él ejercitó una acusación criminal y siendo llevado el acusado a recuperar tal libro y presentarlo a juicio, vio rechazada la acusación - aunque fundada - precisamente porque había escrito tal obra $^{121}$ : obra que claramente no estaba en venta en las librerías públicas y que el autor vanidosamente había hecho circular privadamente, confiando en la discreción de los destinatarios de las copias.

Dentro de los modos de difusión de las obras escritas debe recordarse la lectura pública. Tenemos conocimiento de la importancia del fenómeno en la época clásica, pero éste ya era difundido en la tardía época republicana ${ }^{122}$. Horacio nos habla de poetas que recitaban sus versos en el foro y en el teatro ${ }^{123}$. La novedad introducida por A. Pollinus (primus enim omnium Romanorum advocatis hominibus scripta sua recitavit ${ }^{124}$ ) parece consistir en las recitationes con invitación, celebradas en una sala de propiedad del autor y no en el carácter público de la recitatio. Cabe, así, poner el acento sobre este fenómeno para señalar que junto a éste (y cronológicamente antecedente), per-

unas Capua litteras dedi quibus ad ea rescripsi quae mecum ille de gladiatoribus suis egerat, brevis sed benevolentiam significantis, non modo sine contumelia sed etiam cum maxima laude Pompei. id enim illa sententia postulabat qua illum ad concordiam hortabar. eas si quo ille misit, in publico proponat velim. alteras eodem die dedi quo has ad te. non potui non dare, cum et ipse ad me scripsisset et Balbus. earum exemplum ad te misi. nihil arbitror fore quod reprehendas. si qua erunt, doce me quo modo mempsin effugere possim..) Otro dato a favor es el significado de edere que se recoge en D. 2,13,1,1 (Ulp. 1. 4 ad ed): Edere est etiam copiam describendi facere.

${ }^{119}$ CIC. Att. 3,12,2 en la que el Arpinate lamenta la divulgación de los discursos in Curionem, que él había hecho circular limitadamente y entre personas de confianza.

${ }^{120}$ FEST. sv. Tappulam legem (496 L).

${ }^{121}$ VAL. MAX. 8,1, absol. 8.

122 FUNAIOLI, sv. recitationes, en RE I. A, 1 col. 437 ss.

${ }^{123}$ HOR. sat. 1,4,2: beatus Fannius ultro delatis capsis et imagine, cum mea nemo scripta legat vulgo recitare timentis ob hanc rem, quod sunt quos genus hoc minime iuvat, utpote pluris culpari dignos 1,4,75: in medio qui scripta Foro recitent sunt multi quique lavantes: suave locus voci resonat conclusus. inanis hoc iuvat, haud illud quarentis, num sine sensu, tempore num faciant alieno; epist. 1,19,41 ss.

${ }^{124}$ SEN. contr. 4, praef. 2. 
manece aquel de la lectura privada, hecha ante un público de pocos íntimos, como aquella que Horacio practica ${ }^{125}$, quizá in conviviis et in circulis $^{126}$. Ahora bien, puesto que sabemos que el tono de estos entretenimientos privados era utilizado para la máxima maledicencia y crítica personal (sobre todo cuando el clima político disuadía para manifestar muy ardorosamente el propio pensamiento en público, como durante el triunvirato), es espontáneo pensar que las lecturas de obras difamatorias, intencionadamente, tuviesen lugar en tales ocasiones y la ausencia de publicidad debía asegurar a sus autores, contrariamente a cuanto sucederá en el principado ${ }^{127}$, la más absoluta impunidad.

En conclusión, se puede afirmar que, en la República tardía, la literatura difamatoria habría tenido una circulación, oral o escrita, sólo limitada a ambientes cerrados. Esta circunstancia, unida al hecho de ser la literatura producida y utilizada —en su mayoría - por la clase dirigente y por su clientela, impedía que el escrito difamatorio, al menos en la forma de liber editus, llegase al pueblo y explica porqué en las obras escritas se podían eludir las reglas dispuestas para la difamación oral: en los escritos encontramos el laedere nominatim, y no sólo en aquellos que podemos considerar autorizados en cuanto a la expresión de legitimae disceptationes; encontramos la laudatio y la vituperatio también de los vivos.

Pero junto al supuesto en el que la difamación escrita era fijada al liber editus, hay que añadir el fenómeno de la escrita o la diseñada en folletos esparcidos en la calle o sobre monumentos públicos. Las fuentes literarias designan tales escritos con los términos inscriptio, libellus, epigramma, versus, carmen y biblion, y su difusión con los verbos proponere, proscribere, spargere y ektiqenain ${ }^{128}$. Este tipo de escritos, consistentes como máximo en una frase lapidaria —en prosa o en verso- - y rigurosamente anónima, podía alcanzar aquella forma de publicidad que habitualmente el liber no tenía. Con el anonimato

${ }^{125} \mathrm{HOR}$, sat. 1,4,73: nulla taberna meos habeat neque pila libellos, quis manus insudet vulgi Hermigenisque Tigelli. nec recito cuiquam nisi amicis, dique coactus, non ubivis coramve quibuslibet.

${ }^{126}$ CIC. Att.2,18,1; sobre la maledicencia de las reuniones convivales y en los circuli ver también Balb. 57.

${ }^{127} \mathrm{Al}$ respecto se recuerda la condena de Clutorius Priscus en TAC. ann, 3,49 y el caso del pretor Antisius condenado al exilio por Nerón por haber leído unos versos difamatorios durante un convite (TAC. ann. 14, 48).

${ }^{128}$ Sobre el modo de difamación de tales escritos, se ha analizado en la literatura principalmente en relación con el libellus así véase VON PREMERSTEIN, sv. libellus, cit. col. 27 ss y SAMONATI, sv. libellus, cit. p. 799 ss. 
caía el vis-a-vis y era vano el rescribere (contestar). Así se podía eficazmente organizar y expresar el disenso político y hacer propaganda. Sabemos que al menos hasta la época de Nevio y Catón se difundían epigramas anónimos ${ }^{129}$. El fenómeno es registrado también en época posterior ${ }^{130}$. Pero es en la época del triunvirato cuando este fenómeno parece asumir una gran difusión y una impronta decididamente política, y quizá sea precisamente en esta época cuando el derecho se haya ocupado de él con cierta energía.

Así las innovaciones normativas de las que tenemos conocimiento cierto se centran en la difamación escrita. De éstas, la más relevante, nos la trae el origen de la represión ordinaria privada de tal ilícito. Ulpiano, después de haber citado la cláusula del edicto ne quid infamandi causa fiat ${ }^{131}$ comenta:

D. 47,10,15,27 (Ulp. 57 ad ed): Generaliter vetuit praetor quid ad infamiam alicuius fieri. proinde quodcumque quis fecerit vel dixerit, ut alium infamet, erit actio iniuriarum. haec autem fere sunt, quae ad infamiam alicuius fiunt: ut puta ad invidiam alicuius veste lugubri utitur aut squalida, aut si barbam demittat vel capillos submittat, aut si carmen conscribat vel proponat vel cantet aliquod, quod pudorem alicuius laedat

Entre los casos de aplicación del edicto ne quid infamandi causa fiat el jurista, por tanto, menciona el escrito difamatorio.

Aunque ya se ha dicho que la fecha de emanación de este edicto es incierta, se considera posterior a aquel de convicio y al de aptemptata pudicitia. Servio lo conoce y comenta ${ }^{132}$. Según MANFREDINI la ley silana de iniuriis, convencionalmente publicada en el 81 a. $\mathrm{C}^{133}$, lo presupone y la Rhetorica ad Herennium, de la que al menos el primer libro ha sido publicado después del 88 a.C, parece no hacer mención en un fragmento (Rhet. Her. 4, 25, 35) donde el desarrollo edictal de la iniuria es delineado con una cierta precisión histórica y terminológi-

${ }^{129}$ Se recuerda los versus propositus de Nevio contra los Metelos (CAES. BASS gramm. VI, p. 266 K; los epigramas contra Catón el mayor en PLUT. Cat. mai. 1,3.

130 Se sabe por CIC. ad. Q. fr. 1,3,8 que circulaban en Roma versos anónimos contra la ley Aurelia y que eran falsamente atribuidos a Q. Cicerón. Por QUINT. 8, 3, 29 conocemos que Salustio era objeto de epigramas anónimos y así también un cierto Rufus.

${ }_{131}$ D. 47. 10, 15, 25 (Ulp. 57. ad ed).

132 D. 47. 10, 15,32 (Ulp. 57 ad ed); Según DAUBE, Ne quid...cit. p. 426 la interpretación del jurista correspondería al período de su propia pretura en el año 65 a.C.

${ }^{133}$ ROTONDI, Leges publicae populi Romani, Milano, 1912, p. 359. 
ca a la infamatio ${ }^{134}$. Si aceptamos este indicio, deberíamos considerar que el edicto habría sido emanado en torno a los años de la dictadura de Sila.

Es lícito suponer que la amplia formulación de la cláusula hubiera inmediatamente puesto el problema de contener y determinar casuísticamente la esfera de aplicación ${ }^{135}$. Por tanto, los casos citados por Ulpiano, en un fragmento en el que prevalece la perspectiva histórica del tratamiento del delito de la iniuria, pueden fundadamente ser considerados como los casos originarios en los que fue aplicado tal edicto.

Todo esto nos lleva a afirmar que el edicto ne quid infamandi causa fiat constituyó la base normativa de la represión ordinaria privada del escrito difamatorio; que entre los casos más antiguos en los que tuvo aplicación figuraba este ilícito y que, antes de tal edicto la difamación escrita, no fuese ordinariamente reprimida.

Respecto a qué formas de difamación escrita era perseguida, sobre qué criterios generales inspiradores, y qué frecuencia tuvo tal represión, no lo sabemos. A falta de toda casuística al respecto, no considera MANFREDINI ${ }^{136}$ que las palabras de Ulpiano, deban entenderse como una cita histórica recabada de los más antiguos comentarios ad edictum y de las referencias horacianas contenidas en la sátira dirigida a Trebacio. Ulpiano en D. 47, 10, 15, 27 (Ulp. 57 ad ed) proyecta un supuesto complejo, de dudosa interpretación. El mismo análisis gramatical, sintáctico y semántico es difícil.

El término carmen en singular, parece indicar la individual, breve composición (una sátira o un epigrama) poético ${ }^{137}$; conscri-

${ }^{134}$ Así lo considera FERRINI, Esposizione storica e dottrinale del diritto penale romano, en Enciclopedia del Diritto penale romano, I, Milano, 1905 p. 233 quien reclama como sustento el fragmento de la Coll.2,5,3; También DAUBE, Ne quid...cit. p. 438 analiza el fragmento de la Rhetorica bajo el perfil de la extensión de la iniuria a los diversos supuestos edictales y no lo usa para fechar el edicto ne quid infamandi causa fiat; en efecto, este autor supone que el edicto haya sido emanado entre el $200 \mathrm{y}$ el 100.

${ }^{135}$ Sobre la novedad que representa este edicto véase DAUBE, Ne quid... cit. pp. 417-420; como es conocido según este autor, a la circunstancia de que todo acto realizado con la intención de difamar habría sido formalmente perseguible en virtud de este edicto, se habría obviado a través de la animadversio pretoria o censoria; entre estos figuraba el carmen famosum en cuanto susceptible de producir una nota censoria.

${ }^{136}$ MANFREDINI, La diffamazione, cit.p. 198.

${ }^{137}$ Una definición del carmen famosum de época avanzada y documentada, cree Manfredini una ampliación de tal noción (la sententia 15 de PS 5,4 contenida en el cod. S. Germani 1278: HAENE, Lex Romana Wisigothotum, Lipsae 1848, p. 418) se 
bere $^{138}$ significa componer por escrito; proponere ${ }^{139}$, en relación con los breves escritos, expresa el hecho de divulgar a través de la colocación en lugar público o sobre monumentos. Cantare ${ }^{140}$ es el hecho de entonar o recitar con voz modulada carmina. Laedere pudorem no significa unívocamente dañar la fama, en sentido objetivo, sino que presenta valores subjetivos que reclaman el sentimiento de honor, de la pudicia y de la vergüenza ${ }^{141}$.

Si concebimos proponere y cantare como referidos a carmen además de aliquod y damos particular relevancia a la locución proponere aliquod entendiendo tal verbo en la acepción en la que se considera solvente en las fuentes respecto a los escritos difamatorios, se podría pensar que el fragmento proyecta, como hipótesis general, el caso de los escritos breves o dibujos ofensivos, propositi en lugar público o como hipótesis especial, considerada tal porque casuísticamente más frecuente, aquélla de carmen, aquélla de la breve composición poética que, además de ser divulgada a través de la consignación a terceros del documento que lo contiene (tabulae, membranae ${ }^{142}$ podía también ser recitado o propositum en lugar público.

Esta interpretación nos autorizaría a suponer que, en el momento de acordar una acción privada contra la difamación escrita, el pretor se haya preocupado primeramente del fenómeno de los breves escritos - singulares composiciones poéticas, escrituras sobre monumentos o sobre muros- puesto que podían revestir más fácilmente una forma de publicidad, especialmente, a través de recitare (o cantare) y proponere (o in vulgo edere $)^{143}$. Además nos permite observar que la más antigua especulación jurisprudencial en tema de los escritos difamatorios (la cita de Ulpiano) está orientada a no distinguir, en el ámbito del fenómeno de los breves escritos difamatorios, ningún tipo específico salvo aquél del carmen. Junto al carmen está el aliquod

colige como significado fundamental y originario aquel de sátira y epigrama. El valor de breve composición parece que se presupone por la doctrina.

${ }^{138}$ FORCELLINI, shv. signif. 4.

${ }^{139}$ FORCELLINI, shv. signif. $1 . \mathrm{a}, \mathrm{b}$.

${ }^{140}$ FORCELLINI, shv. signif. II, 1.

${ }^{141}$ Así DAUBE, Ne quid cit. p. 421. Las fuentes jurídicas citadas por este autor, en las cuales establece una relación entre pudor y fama, acreditan esta idea son D. 2,4,12 (Ulp. 1. 5 ad ed); D.3,2,20 (Pap.1. 1 resp.); D. 47, 10, 1,5 (Ulp. 56 ad ed).

${ }_{142}$ Sobre el uso del material de escritorio por parte de los poetas para su poesía extemporánea véase MARQUARDT, La vie privée, cit. p. 472.

${ }^{143}$ Con ello MANFREDINI no quiere decir que el escrito largo, publicado como $l i$ ber editus, no entrase en la previsión del edicto sino que, en el análisis jurisprudencial, esta figura, a la par del libellus, no es todavía distintamente considerada. (nota 27, p. 200). 
que comprende, además del graffiti, todas las formas que la historiografía contemporánea tiende a indicar como libelli publice propositi ad infamiam alicuius conscripti y a asimilarlos al carmen ${ }^{144}$.

La jurisprudencia, en este periodo, no asume el término libellus en la descripción del fenómeno de la difamación escrita. Esto sucederá sólo en época clásica y más tarde cuando a la alocución libelli aut carmina ${ }^{145}$ se atribuya el valor de un antítesis entre los escritos de delación, de denuncia de graves culpas y todos los otros escritos difamatorios, de carácter polémico, satírico o dañino. Los libelli famosi de los que se ocupan los juristas de época avanzada son las denuncias calumniosas ${ }^{146}$, que las constituciones tardoimperiales reprimen con extrema severidad — si son anónimas- pero frente a las que también se admite la represión privada ${ }^{147}$.

144 Th.l.1. sv. libellus signif. I, A, 3 f. Por esto cree Manfredini que la figura del $l i$ bellus famosus, en el sentido de escrito satírico, de invectiva y no de escrito delatorio sea de creación historiográfica y que no encuentren una autónoma consideración ni en el lenguaje normativo ni en aquel jurisprudencial; tanto es así que al acto de individualizar la exacta connotación jurídica, la historiografía asimila el libellus famosus al carmen famosum, así véase: THEDENAT, sv. libellus famosus, carmen famosum, cit. p. 1176; VON PREMERSTEIN, sv. libellus, cit. col. 29. PFAFF, sv. liber (oder libellus) famosus, cit. col. 61; SAMONATI, sv. libelli, cit. p. 817; BRASIELLO, sv. libellus famosus, cit. p. 828 quien únicamente especifica que en época imperial la locución se tecnifica.

${ }^{145}$ Gayo, 3,220; PS, 5,4, 15.17; I. 4,4,1.

146 Sobre la calumnia véase la obras de GARCÍA CAMIÑAS, Delator: una aproximación al estudio del delator en las fuentes romanas (Santiago de Compostela, 1983); La lex remmia de calumniatoribus (Santiago de Compostela, 1984; ISBN.: 84-7191-333-X); Ensayo de reconstrucción del título ix del edicto perpetuo «de calumniatoribus» (Santiago de Compostela, 1994; «Sobre los quadruplatores» en Studia et Documenta Historiae et Iuris, Roma, 1, 1984, p. 461-520; «Le crimen calumniae dans la lex Remmia de calumniatoribus» en Revue Internationale des Droits de l'Antiquité, Bruselas, XXXVII, 1990. p. 117. «Presupuestos textuales para una aproximación al concepto de calumnia en el proceso privado romano» en Seminarios Complutenses de Derecho romano, Madrid, 1992, III, p. 27-51; "Régimen jurídico del iusiurandaum calumniae» Studia et Documenta Historiae et Iuris, Roma, 1994, LX, p. 457-468; «Acerca del senadoconsulto Turpiliano» en Estudios de Derecho romano en memoria de Benito Ma Remundo Yanes, Burgos, 2000, I, p. 93-102; ·Régimen jurídico del iudicium calumniae decimae partis» en Anuario de la Facultad de Derecho de la Universidad de La Coruña, 2000, p. 227.239; «La acción edictal de calumnia al cuádruplo» en Anuario de la Facultad de Derecho de la Universidad de La Coruña, 2001, p. 343-365; «Naturaleza del proceso criminal de calumnia» en Libro Homenaje a Ildefonso Sánchez Mera, Madrid, 2002, p. 45-54; «La acción edictal de la calumnia al cuádruplo» en Estudios Juridicos in memoriam del Profesor AlfredoCalonge, Salamanca, 2002, p. 395-420; «El iusiurandum calumniae en la editio actionis y en la editio rationum del argentarius» en Anuario de la Facultad de Derecho de la Universidad de La Coruña, 2004, p.. 369-412.

${ }_{147}$ D. 47, 10, 15, 29 (Ulp. 57 ad ed): el libellus allí mencionado no es un escrito difamatorio (WITTMANN, Die Entwicklungslinien, cit. p. 328) sino un escrito de súplica (RABER, Grundlagen. cit. p. 63) o de denuncia dirigido al príncipe o a funcionarios. 
De cualquier modo, en los orígenes, la figura del carmen conscriptum quod pudores alicuius laedat, primigenia sobre todo otro género de escrito difamatorio. Ésta constituye el tronco del que desciende el carmen famosum. Esta locución, que encontramos en las fuentes no técnicas a partir de Horacio y Séneca ${ }^{148}$ el rétor, en el lenguaje jurisprudencial de época clásica y posterior aparece con cierta frecuencia ${ }^{149}$ y parece designar, emblemáticamente, todo tipo de escritura de invectiva que no sea un escrito delatorio: carmen facit non tantum, qui satyras et epigrammata, sed illegitimam insectandi alicuius causa, quidve aliud alio genere componit ${ }^{150}$. El carmen y el aliquod quod pudores alicuius laedat del texto de Ulpiano, del que nos ocupamos, confluyen unitariamente en la noción del carmen famosum.

Si bien este fragmento de Ulpiano nos ofrece noticias en torno a los géneros y a las formas de difamación escrita a las que comúnmente se dirige, al acto de su institución, la represión ordinaria privada, nada nos dice sobre los criterios generales a los que se pueda inspiraba en su concreto ejercicio.

Alguna noticia, al respecto, podemos deducir de la obra de Horacio. En efecto, está fundado suponer que el poeta, cuando menciona, en la sátira 2,1 , el ius y el iudicium que regía en el tema de la poesía difamatoria (como es conocido él en este fragmento habla de malum carmen) tienda a referirse al edicto ne quid infamandi causa fiat y a la actio iniuriarum que corresponde. Podemos deducir que los argumentos apologéticos, desarrollados en este texto se dirigiesen idealmente a la actio iniuriarum ex edicto ne quid... En éstos podemos encontrar los criterios generales que, en la aplicación a un caso de difamación escrita, inspiraban el concreto ejercicio de la acción o bien, los factores y las condiciones por las que dependía el reconocimiento de la responsabilidad. Por ello podemos suponer que a ésta se pudiese llegar cuando el escrito difamatorio presentaba las siguientes connotaciones: un escrito que no circulaba en ámbito restringido sino que era vendido en librerías; un escrito que no era recitado en privado sino en público (se nota todavía el gran peso que tenía la publicidad), un escrito a cuya licentia el autor no pudiera contraponer su virtus, y ésta a la improbidad del difamado; un escrito que no fuese una respuesta a una precedente difamación y —en opinión de

${ }^{148}$ Hor. epist. 1, 19,31; Sen. Contr 5, 6.

149 D. 22. 5,21; D. 28.1.18.1; PS 5,4,6.15.

150 PS 5, 4, 15. carmen facit non tantum, qui satyras et epigrammata, sed illegitimam insectandi alicuius causa, quidve aliud alio genere componit. 
MANFREDINI- un escrito cuyo autor no pudiese buscar la protección de los poderosos.

A estos requisitos, que traemos directamente de las palabras de Horacio, añadiríamos sin duda la naturaleza no de iocus, de levitas ni de urbanitas del escrito. La posibilidad de que éstos tuvieran jurídica relevancia reposaba en el ejercicio de la animadversio ${ }^{151}$ pretoria, a través de la cual el magistrado decidía libremente si concedía o negaba la acción en caso de infamatio.

Que en la aplicación de estas reglas — según MANFREDINI ${ }^{152}$ — se favoreciese lo personalísimo y se protegiese intereses particulares y de clase, es posible; que en virtud de éstos -y sobretodo de aquella que autorizaba a divulgar la improbidad de otro- se ha acordado la máxima tolerancia a la difamación, incluso escrita, es probable. Pero al respecto no debe olvidarse que las fuentes no nos atestiguan ningún caso de aplicación de la actio iniuriarum ex edicto ne quid infamandi causa fiat por la difamación escrita.

${ }^{151}$ D. $47,10,15,25.28$.

${ }^{152}$ MANFREDINI, La diffamazione, cit. p. 204. 